\title{
PUTATIVE MINERAL-SPECIFIC PROTEINS SYNTHESIZED BY A METAL REDUCING BACTERIUM
}

\author{
BRIAN H. LOWER*', MICHAEL F. HOCHELLA, JR.**, and STEVEN K. LOWER***
}

ABSTRACT. Biological force microscopy (BFM) was combined with two-dimensional gel electrophoresis and mass spectrometry to search for evidence of putative mineral-specific outer membrane proteins (OM) synthesized by Shewanella oneidensis for Fe-oxide binding and/or anaerobic Fe(III) reduction. BFM shows that $S$. oneidensis possess an affinity towards goethite $(\mathrm{FeOOH})$ but not diaspore $(\mathrm{AlOOH})$ under anaerobic conditions, despite the fact that diaspore is isostructural with goethite and has essentially the same surface charge. The worm-like chain model was used to identify force-signatures indicative of putative OM polypeptides that bind to goethite. Two-dimensional protein expression patterns show that over $100 \mathrm{OM}$ proteins are differentially expressed under aerobic versus anaerobic $\mathrm{Fe}(\mathrm{III})$ reducing conditions. Peptide mass fingerprinting and tandem mass spectrometry were used to identify several of the protein spots predominately detected when Fe(III) was the terminal electron acceptor. Among those identified were proteins involved in metal reduction, protein transport and secretion, polysaccharide biosynthesis and export, and hypothetical proteins with unknown functions. A comparison of the BFM and proteomic data suggest that a few specific $O M$ proteins are synthesized by $S$. oneidensis under anaerobic conditions to function in iron oxide binding and/or $\mathrm{Fe}$ (III) reduction. This suggests the intriguing possibility that metal reducing bacteria contain the genetic repertoire to make proteins directed at specific inorganic phases.

\section{INTRODUCTION}

Enzymatic electron transfer reactions between dissimilatory iron-reducing bacteria (for example, Shewanella and Geobacter) and iron oxyhydroxides are believed to have originated billions of years ago and may represent the first globally significant mechanism for oxidizing organic matter to carbon dioxide (Lovley, 1991; Lovley and others, 1991a, 1991b; Vargas and others, 1998). At the present time, this form of iron reduction accounts for the majority of iron valence transition in anaerobic nonsulfidogenic environments (Fredrickson and Gorby, 1996). Iron-reducing microorganisms have received a great deal of attention in the literature over the last decade because of, among other things, their unique ability to couple the oxidation of organic contaminants to $\mathrm{Fe}(\mathrm{III})$ reduction in anaerobic environments (Lovley, 2001). Biological coupling of the oxidation of natural and anthropogenic carbon to the $\mathrm{Fe}$ (II)-Fe(III) redox reaction appears to account for a major flux in energy at the Earth's surface, both spatially and temporally.

The generation of energy by electron transport coupled reduction of $\mathrm{Fe}$ (III) presents a rather intriguing challenge to microorganisms. This is because $\mathrm{Fe}$ (III) in the environment (both now and in much of the geologic past) exists predominantly as a solid phase such as ferrihydrite, goethite, and hematite. Given that iron oxyhydroxides are effectively insoluble at the earth's surface, it seems probable that any proposed enzymatic mechanism for the reduction of $\mathrm{Fe}$ (III) must involve direct contact between a bacterium's outer membrane (OM) and a metal oxide surface (Lovley and Phillips, 1986; Arnold and others, 1988; Lovley and Phillips, 1988; Arnold and others, 1990;

*Environmental Molecular Sciences Laboratory, Pacific Northwest National Laboratory, P.O. Box 999, K8-96, Q-Avenue, Richland, Washington 99352

**Department of Geosciences, Nanogeoscience and Technology Laboratory, Virginia Tech, Blacksburg, Virginia 24061

***Ohio State University, 125 South Oval Mall, 275 Mendenhall Laboratory, Columbus, Ohio 43210

+Corresponding author: brian.lower@pnl.gov 
Myers and Nealson, 1990; Roden and Zachara, 1996; Caccavo and others, 1997; Myers and Myers, 1997; Fredrickson and others, 1998; Zachara and others, 1998; Urrutia and others, 1999; Rosso and others, 2003). Unlike oxygen, Fe(III) in a solid form cannot diffuse across the $\mathrm{OM}$ to the cytosolic membrane, which in most organisms, is the location of the enzymes responsible for electron transfer, proton translocation, and production of adenosine triphosphate. Certain Gram-negative, dissimilatory ironreducing bacteria (for example, $S$. oneidensis), which are common in soils, surface waters, and subsurface environments, have developed a resourceful solution to this problem by using a unique system of proteins that shuttle electrons from an energy source in the cytoplasm, across the cytosolic membrane and periplasmic space to the bacterium's OM (Myers and Myers, 1992; Myers and Myers, 2000). Once there, putative iron reductases transfer the electrons directly to Fe(III) in the crystal structure of Fe(III)-bearing minerals (Arnold and others, 1988; Myers and Myers, 1992; Myers and Myers, 1998). It is important to note that others have recently shown that iron-reducing bacteria may possess a richer repertoire of mechanisms to reduce $\mathrm{Fe}(\mathrm{III})$ oxyhydroxides that also includes extracellular quinones (Newman and Kolter, 2000; Hernandez and Newman, 2001).

In light of observations that iron reduction is a rudimentary biogeochemical process requiring (in many cases) direct contact between a microorganism and mineral, we would like to determine whether the close intimacy between $S$. oneidensis and iron oxyhydroxides is preserved in the genetic makeup of this species such that it produces mineral-specific proteins. Early reports by our group suggest an intriguing possibility that bacteria can indeed recognize inorganic crystalline surfaces (Lower and others, 2001a). Here we used biological force microscopy (BFM) in combination with two-dimensional (2D) gel electrophoresis and protein mass spectrometry to look for evidence of inducible proteins produced exclusively to mediate contact with a specific mineral.

These techniques provided highly complementary data suggesting that $S$. oneidensis actively recognizes iron oxyhydroxides under anaerobic conditions and targets $\mathrm{OM}$ proteins to its interface with goethite. The specificity of these OM proteins appears to be remarkable as $S$. oneidensis exhibited a selective disposition towards goethite $(\mathrm{FeOOH})$ relative to diaspore $(\mathrm{AlOOH})$. This natural affinity between $S$. oneidensis and goethite is, presumably, a vestige of the strong evolutionary linkage between dissimilatory metal reducing bacteria and ferric minerals.

\section{MATERIALS AND METHODS}

\section{Bacteria, Media, and Minerals}

S. oneidensis MR-1 (ATCC 700550) was purchased from the American Type Culture Collection (Manassas, VA) and cultured at 22 to $25^{\circ} \mathrm{C}$ and $\mathrm{pH} \sim 7.4$ in defined M1 medium (Myers and Nealson, 1988). M1 medium consisted of $9.0 \mathrm{mM}\left(\mathrm{NH}_{4}\right)_{2} \mathrm{SO}_{4}$,

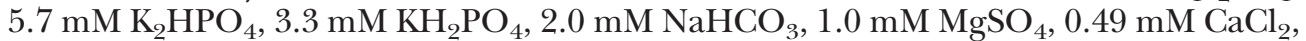
$67.2 \mu \mathrm{M}$ disodium EDTA, $56.6 \mu \mathrm{M} \mathrm{H}_{3} \mathrm{BO}_{3}, 10.0 \mu \mathrm{M} \mathrm{NaCl}, 5.4 \mu \mathrm{M} \mathrm{FeSO}, 5.0 \mu \mathrm{M}$ $\mathrm{CoSO}_{4}, 5.0 \mu \mathrm{M} \mathrm{Ni}\left(\mathrm{NH}_{4}\right)_{2}\left(\mathrm{SO}_{4}\right)_{2}, 3.9 \mu \mathrm{M} \mathrm{Na}_{2} \mathrm{MoO}_{4}, 1.5 \mu \mathrm{M} \mathrm{Na}_{2} \mathrm{SeO}_{4}, 1.3 \mu \mathrm{M} \mathrm{MnSO}_{4}$, $1.0 \mu \mathrm{M} \mathrm{ZnSO}_{4}, 0.2 \mu \mathrm{M} \mathrm{CuSO}_{4}, 0.1 \mathrm{~g} / \mathrm{L}$ vitamin-free Casamino Acids, $20 \mu \mathrm{g} / \mathrm{mL}$ L-arginine, $20 \mu \mathrm{g} / \mathrm{mL}$ L-glutamate, and $20 \mu \mathrm{g} / \mathrm{mL}$ L-serine. For anaerobic cultures, M1 medium was supplemented with $15 \mathrm{mM}$ lactate as the carbon and energy source and $2 \mathrm{mM}$ ferric citrate (or ferric NTA) as the electron acceptor. Stock cultures were grown in $25 \mathrm{~g} / \mathrm{L}$ Luria-Bertani (LB) medium (Fisher Scientific, Pittsburg, PA), pH $\sim 7.4$, and maintained in 30 to 40 percent (v/v) glycerol at $-80^{\circ} \mathrm{C}$.

For aerobic growth, a glass bottle containing M1 medium was inoculated with an overnight, aerobic culture and grown with vigorous aeration using a shaker table or, in some experiments, a magnetic stir plate while bubbling media with filter $(0.2 \mu \mathrm{m})$ 
sterilized air. Anaerobic growth was performed in a similar manner with the following exceptions: the medium was made anaerobic by first boiling the MilliQ water used to prepare the medium and then purging the prepared media for 20 to 30 minutes with filter $(0.2 \mu \mathrm{m})$ sterilized oxygen free $\mathrm{N}_{2}: \mathrm{CO}_{2}(95: 5)$ or $\mathrm{N}_{2}$; all anaerobic culture manipulations were performed inside an anaerobe chamber (Coy Laboratory Products, Ann Arbor, MI) with an atmosphere of $\mathrm{N}_{2}: \mathrm{H}_{2}$ (95:5); glass bottles were stopped with butyl rubber stoppers; air was not bubbled through the cultures. Cells were harvested at exponential growth phase by centrifugation. These cells were either used immediately in BFM experiments (see below), or the cell pellet was stored at $-20^{\circ} \mathrm{C}$ until proteins were extracted for 2D gel electrophoresis (see below).

\section{Biological Force Microscopy}

Biologically-active-force-probes (Lower and others, 2000, 2001b; Kendall and Lower, 2004) were fabricated by linking living $S$. oneidensis cells to a small bead $(\sim 10$ $\mu \mathrm{m}$ diameter) attached to the end of a silicon nitride cantilever. Scanning laser confocal microscopy was used to confirm monolayer coverage of cells on the bead attached to the cantilever (Lower and others, 2000). Prior to growth in media, $S$. oneidensis cells were transformed with a plasmid (pSMC2; provided by G. O'Toole, Dartmouth College) encoding a green fluorescent protein. Fluorescence emission provided a convenient, non-invasive means of characterizing the localization of bacteria on the force-sensing cantilever. Each biologically-active-force-probe was placed on an LB agar plate subsequent to force measurements. For the data presented herein, a distinctive, single reddish colony (indicative of $S$. oneidensis) was observed growing on the agar directly under the end of each of the cantilevers used in replicate force microscopy experiments. This indicated that cells were indeed living and active during force measurements. No bacterial colonies were detected on plates inoculated with control probes, which consisted of silicon nitride cantilevers supporting small beads attached to the end of the lever with epoxy.

Commercial force microscopes (NanoScope IIIa Multimode SPM and NanoScope IV Bioscope, Veeco-Digital Instruments) were used to measure attractive or repulsive forces between living $S$. oneidensis and minerals (goethite, FeOOH; or diaspore, $\mathrm{AlOOH}$; both from the Virginia Tech Geological Sciences Museum) in anaerobic or aerobic solutions (1-10 mM NaCl) supplemented with lactate. Mineral crystals were cleaned by agitation in ultrapure water (Milli-Pore), acetone, and ethanol to remove adventitious carbon (Stipp and Hochella, 1991). Deflection (upwards or downwards) of a biologically-active-force-probe was measured as an oriented mineral crystal was indexed towards (approach data) and then retracted from a biologically-active-forceprobe after making contact with the bacteria (retraction data). The deflection of the probe was recorded in volts by reflecting a laser off the top of the biologically-activeforce-probe and into a photodiode detector. The photodiode response was converted into deflection (in $\mathrm{nm}$ ) by using a conversion factor, called the optical lever sensitivity $\left(\sim 55 \mathrm{~nm} \mathrm{~V}^{-1}\right)$. The measured spring constant $\left(0.07 \mathrm{nN} \mathrm{nm}^{-1}\right.$; Cleveland and others, 1993) of the biologically-active-force-probe was used to convert deflection (in $\mathrm{nm}$ ) into a force of interaction (in nanoNewtons, $\mathrm{nN}$ ).

We used the photodiode shift voltage (D'Costa and Hoh, 1995; Lower and others, 2001b), as opposed to the region of constant compliance (Ducker and others, 1992), to determine the optical lever sensitivity for these experiments. It is important to note that we would have overestimated the magnitude of measured forces had we used the so-called region of constant compliance to determine the optical lever sensitivity. For example, the region of constant compliance for $S$. oneidensis-goethite interactions under anaerobic conditions yielded an average of $\sim 170 \mathrm{~nm} \mathrm{~V}^{-1}$ for the optical lever sensitivity. The compliance of the cells relative to the cantilever accounts for the significant difference between the two methods used to determine optical lever 
sensitivity. We have previously discussed the importance of using the photodiode shift voltage with living cells that are more compliant than the force-sensing cantilever (Lower and others, 2001b).

Separation distance was determined by correcting the displacement of the piezoelectric scanner by the deflection of the cantilever, and selecting the point of contact using jump-to-contact and jump-from-contact events for approach and retraction curves, respectively (Lower and others, 2000, 2001b; Kendall and Lower, 2004). Force-separation curves were analyzed with an integrated software program designed for the analysis and presentation of force data (kindly provided by $\mathrm{T}$. Kendall). This program runs off of the Igor Pro platform and is described in Kendall and Hochella (2003) and Kendall and Lower (2004).

\section{Two-dimensional Gel Electrophoresis and Protein Identification}

The method for extraction and enrichment of OM proteins from Gram-negative bacteria was slightly modified from Molloy and others (2000). The method we used employs a differential solubilization protocol applicable to whole cell lysate (Fujiki and others, 1982; Molloy and others, 2000; Santoni and others, 2000; Molloy and others, 2001). A sodium carbonate ( $\mathrm{pH}$ 11) solution is used to solubilize cytoplasmic and peripheral proteins, leaving the remaining insoluble material enriched in OM proteins. A centrifuge is used to collect the OM fraction, which is then prepared for $2 \mathrm{D}$ gel electrophoresis.

Approximately $1 \mathrm{~g}$ wet cell pellet was resuspended in ice cold $10 \mathrm{~mL} 10 \mathrm{mM}$ Tris-base, $\mathrm{pH}$ 8.1, containing $10 \mu \mathrm{g} / \mathrm{mL}$ DNaseI, $10 \mu \mathrm{g} / \mathrm{mL}$ RNaseA, $1 \mathrm{mM}$ phenylmethanesulfonyl fluoride (PMSF), 1X bacterial protease inhibitor cocktail (Sigma, St. Louis, Missouri), and kept on ice. Lysozyme was added to $0.5 \mathrm{mg} / \mathrm{mL}$ and the cells were lysed immediately by two passages through a French Press at 12,000 lbs/in ${ }^{2}$ and $4^{\circ} \mathrm{C}$. Cell debris and remaining whole cells were removed by low spin centrifugation at $1500 \mathrm{xg}, 4^{\circ} \mathrm{C}$, for 10 minutes. The supernatant was diluted with ice cold $100 \mathrm{mM}$ sodium carbonate, $\mathrm{pH} 11.0$, to a final volume of $100 \mathrm{~mL}$ and stirred slowly for 1 hour at $4^{\circ} \mathrm{C}$. The carbonate treated membranes were collected by ultracentrifugation at $4^{\circ} \mathrm{C}$ for 130 minutes at 49,000 rpm (159,000 xg average) in a Beckman-Coulter type 50 Ti rotor. The resulting pellet, now enriched with OM proteins, was washed twice with ice cold $50 \mathrm{mM}$ Tris-base, $\mathrm{pH} 7.5$, centrifuged for 30 minutes as described above and kept on ice.

The pellet was solubilized in $1 \mathrm{~mL}$ of protein extraction solution containing $6 \mathrm{M}$ urea, 2 M thiourea, 2 percent $(\mathrm{w} / \mathrm{v})$ CHAPS, 2 percent $(\mathrm{w} / \mathrm{v})$ caprylyl sulfobetaine (SB3-10), $2 \mathrm{mM}$ tributyl phosphine (TBP), 0.5 percent (v/v) Triton X-100, $40 \mathrm{mM}$ Tris-base. The sample was placed in an ultrasonic bath at $10^{\circ} \mathrm{C}$ for 5 minutes and then agitated with a vortex mixer to facilitate solubilization of the membrane proteins. This was repeated several times until the entire pellet was solubilized. The sample was clarified by centrifugation at 12,000 $\mathrm{xg}$ for 10 minutes at room temperature and stored at $-20^{\circ} \mathrm{C}$. Protein concentration was determined using the 2DQuant Kit from Amersham Biosciences (Uppsala, Sweden).

Two-dimensional gel electrophoresis was performed as described by Gorg and others $(1985,1988)$ using immobilized $\mathrm{pH}$ gradient (IPG) strips for the firstdimension. An $18 \mathrm{~cm} \mathrm{pH} 3$ to 10 (or $\mathrm{pH} 4-7$ ) Immobiline Dry Strip (Amersham Biosciences) was rehydrated overnight with $340 \mu \mathrm{L}$ of membrane protein extraction solution containing 2 percent (v/v) IPG Buffer $\mathrm{pH} 3$ to 10 (Amersham Biosciences) and 200 to $300 \mu \mathrm{g}$ of the solubilized membrane proteins. Isoelectric focusing was conducted for 75,000 volt-hour (Vh) using an Ettan IPGphor system (Amersham Biosciences) at $20^{\circ} \mathrm{C}$. Prior to second-dimension sodium dodecyl sulfate polyacrylamide gel electrophoresis (SDS-PAGE), IPG strips were equilibrated twice, 15 minutes each, on a rocker table in $10 \mathrm{~mL} 50 \mathrm{mM}$ Tris-HCl, $\mathrm{pH} 8.8,2$ percent (w/v) SDS, $6 \mathrm{M}$ 
urea, 30 percent (v/v) glycerol, trace bromophenol blue. The first equilibration step contained $100 \mathrm{mg}$ DTT and the second equilibration step contained $250 \mathrm{mg}$ iodoacetamide. IPG strips were then embedded onto an $18 \times 18 \mathrm{~cm} 10$ percent SDS-PAGE gel with 1 percent (w/v) agarose in SDS electrophoresis buffer [25 mM Tris-HCl, $\mathrm{pH} 8.3$, $192 \mathrm{mM}$ glycine, 0.1 percent (w/v) SDS] and second dimension separation was performed using an Ettan DALTsix electrophoresis unit (Amersham Biosciences) and the Laemmli buffer system (Laemmli, 1970).

Gels were run at $15^{\circ} \mathrm{C}$ and $5 \mathrm{~W}$ per gel until the bromophenol blue had traversed the gel, stained with SYPRO Ruby (Molecular Probes, Eugene, Oregon) and imaged using a Storm 860 laser scanner (Amersham Biosciences). Quantitative analysis of the 2D gel images (triplicate 2D gels were run per biological sample) was performed using the Delta2D 3.1 software (DECODON, Greifswald, Germany; for a more detailed description, see the Delta2D 3.1 user manual). Briefly, protein spot match vectors were manually added to $\sim 100$ corresponding protein spots in the different $2 \mathrm{D}$ gels thereby allowing gels to be warped and compared. Next, protein spots were identified, background noise subtracted, and normalized quantities compared between the two gels. Only those protein spots with expression ratios of less than 0.5 or greater than 2.0 were considered to differ significantly in abundance.

Protein spots were excised using a clean razor blade and stored at $-20^{\circ} \mathrm{C}$ until needed. In-gel tryptic digestion and mass spectrometry (MS) was performed by the Michigan Proteome Consortium (University of Michigan, Ann Arbor, Michigan) using a 4700 Proteomic MALDI TOF-TOF Analyzer (Applied Biosystems, Framingham, California). For protein identification, we preformed both automated and manual database searches using the Matrix Science Mascot PMF and Mascot MS/MS search engines. Proteins having a probability score $(p)$ of less than 0.05 , where $p$ is the probability that the observed match is a random event, were considered to be positively identified.

\section{RESULTS}

\section{Biological Force Microscopy and Theoretical Worm-like Chain Model}

Force microscopy was used to directly measure inter- and intra-molecular forces as S. oneidensis approached and was subsequently retracted from a mineral surface. The minerals goethite $(\mathrm{FeOOH})$ and diaspore $(\mathrm{AlOOH})$ were used in the BFM experiments. These minerals were selected because they are isostructural and have very similar surface properties (for example, surface charge and hydrophobicity), but only goethite can be used as a terminal electron acceptor for respiration. Force measurements between $S$. oneidensis and each of the minerals were carried out in either aerobic or anaerobic solutions containing lactate as an energy source. We also measured forces at the bacterium-mineral interface as a function of the amount of time $S$. oneidensis remained in contact with a particular mineral. This step was taken to determine whether $S$. oneidensis required a certain period of time to "recognize" a specific inorganic surface.

Figures 1A and 1B illustrate approach and retraction forces, respectively, observed for $S$. oneidensis that were not permitted a period of time in contact with goethite. As $S$. oneidensis approached to within $10 \mathrm{~nm}$ of the goethite surface, attractive forces caused the bacterium to make contact with the mineral to a maximum force of $\sim 0.2 \mathrm{nN}$ (fig. 1A). Individual approach traces appear to deviate from or oscillate around the horizontal line of zero force at separations greater than $10 \mathrm{~nm}$ (see fig. 1A). It is unlikely that these deviations actually represent a true force of interaction. Rather, this is more likely the result of "noise" due to electrical and mechanical vibrations, and thermal fluctuations, which are known to produce artifacts in approach data (Jaschke and Butt, 1995). This "noise", which will be discussed again below, is removed when the 

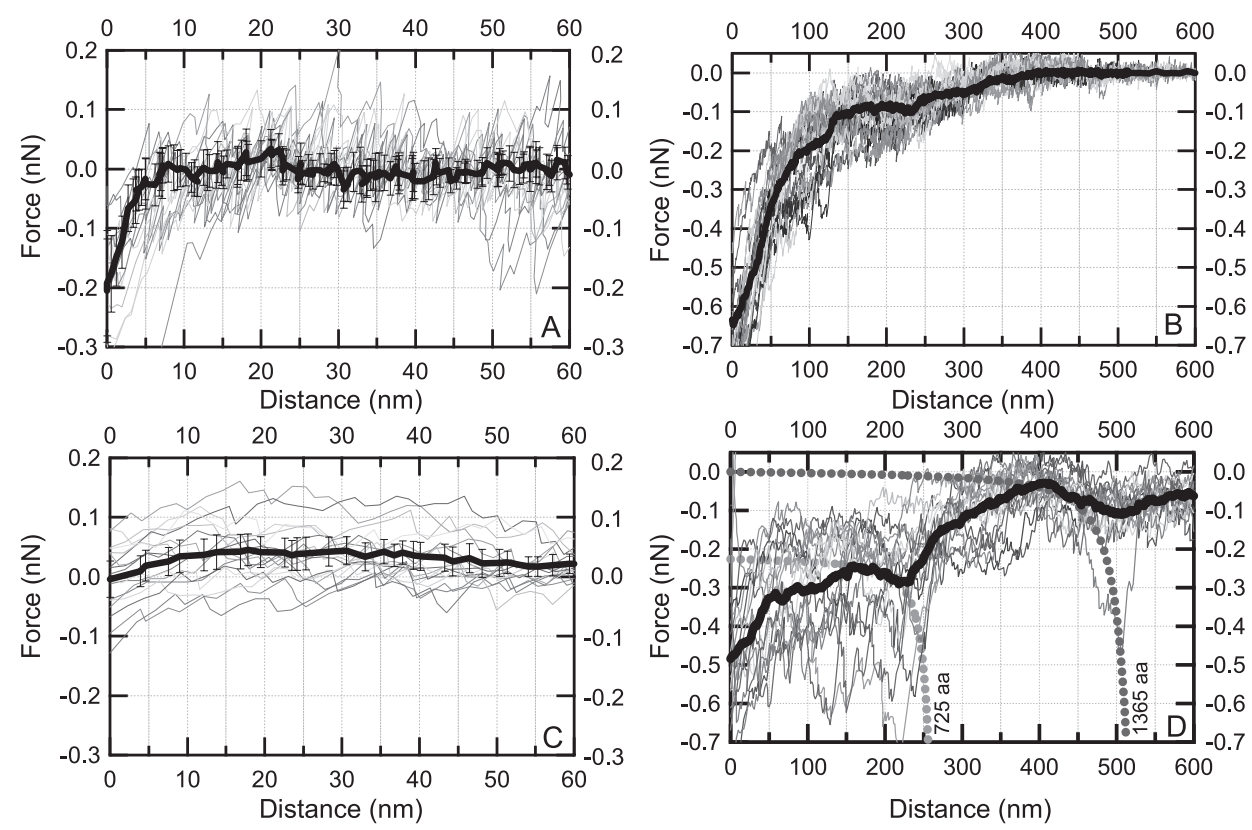

Fig. 1. Force-distance measurements for S. oneidensis and the (010) surface of goethite in anaerobic solutions supplemented with lactate as an electron source. Positive force values indicate repulsion whereas negative values indicate attraction. Traces correspond to individual approach or retraction curves, and the solid black lines correspond to the average traces. Error bars corresponding to the $95 \%$ confidence interval are shown for two of the plots. Error bars for the other two plots are of the same magnitude, but they have been omitted for clarity. Plots (A) and (B) correspond to approach and retraction forces, respectively, for forces detected between $S$. oneidensis and goethite without a period of "recognition time". Plots (C) and (D) correspond to approach and retraction forces, respectively, collected after $S$. oneidensis was placed in contact with goethite 20-25 min (that is, $S$. oneidensis was given time to recognize goethite). The dotted, black curves in panel (D) correspond to the theoretical unfolding relationship between force and distance for two putative polypeptides as predicted by the worm-like chain model. Each number (725 and 1365) corresponds to the contour length (in number of amino acids) of a particular outer membrane protein.

approach data are averaged (see the average trace in fig. 1A). After S. oneidensis made contact with the surface of a mineral, it was pulled away resulting in retraction data like that shown in figure $1 \mathrm{~B}$. These retraction data show a strong attractive force that extends outwards for over $300 \mathrm{~nm}$.

A 5-minute period of time was all that was necessary to collect the data presented in figures $1 \mathrm{~A}$ and $1 \mathrm{~B}$. After this interval, the piezoelectric scanner was used to gently translate the mineral until it just came into contact with a cell on the biologically-activeforce-probe. S. oneidensis cells were allowed to remain in direct physical contact with the goethite (or diaspore) for a period of $\sim 20$ minutes, and then approach-retraction measurements were taken again over a 5 -minute period. This procedure provided $S$. oneidensis with a chance to sense and respond to a specific inorganic crystalline surface, a so-called "recognition time".

Unlike figure 1A, a jump-to-contact feature was not observed in the approach curves for $S$. oneidensis cells that had been given a period of "recognition time" with goethite (fig. 1C). In some instances, it appears that small magnitude repulsive forces (positive values) were present within a range of 5 to $50 \mathrm{~nm}$ (see fig. 1C). Attractive forces are clearly absent in approach data collected after cells were allowed a long period of "recognition time".

Retraction force measurements are markedly different when $S$. oneidensis was provided a chance to "recognize" the surface of goethite (for example, compare fig. 1B 
versus 1D). A striking feature of the retraction profiles shown herein-particularly in figure $1 \mathrm{D}$-is a series of jagged sawtooth like features. These are regions of the retraction curve where the force increases nonlinearly and then suddenly recoils back towards the line of zero force. These sawteeth extend outwards for several hundred $\mathrm{nm}$ (fig. 1D). Many of the same saw-teeth are detected again and again in successive retraction traces.

In an effort to explain the origin of the sawteeth detected between $S$. oneidensis and goethite we turned to a theoretical model called the worm-like chain model (Flory, 1989), which is designed to predict the force necessary to extend a linear polymer such as a protein or nucleic acid. We hypothesized that the observed sawteeth would agree with the worm-like chain model, if the sawteeth in the retraction curves were due to the extension of bridging macromolecules (such as proteins) that formed an attractive bond between the bacterium and goethite.

The worm-like chain model treats a linear molecule as an entropic spring that curves smoothly due to thermal fluctuations in water (Flory, 1989). This model predicts the force $(F)$ necessary to stretch a polypeptide to a length $x$, as:

$$
F(x)=(k T / b)\left[0.25(1-x / L)^{-2}+x / L-0.25\right]
$$

where $k$ is the Boltzmann's constant, $T$ is the temperature, $b$ is the persistence length, which is $\sim 0.4 \mathrm{~nm}$ for the distance between two $\mathrm{C}_{\alpha}$ atoms in a polypeptide (Rief and others, 1997; Mueller and others, 1999), and $L$ is the contour length (that is, the length of the completely stretched polymer). As shown by equation 1, the worm-like chain model predicts a highly nonlinear response between force and the extension. When a polymer is extended by a relatively small amount, the force is expected to increase linearly with the extension distance; whereas at long range extension (that is, were $x$ approaches $L$ ) the force deviates significantly from a linear function.

Each observed sawtooth feature may represent a discrete and unique macromolecule that is stretched as a bacterium is pulled from goethite. For the purposes of this paper we will focus attention on the average retraction curve between $S$. oneidensis and goethite (see fig. 1D). While the averaging procedure smears the details of individual traces, at least two prominent saw-teeth are still evident. One sawtooth is observed beginning at approximately $200 \mathrm{~nm}$, while the other can be found beginning at an extension distance of $400 \mathrm{~nm}$ (see fig. 1D). For a protein persistence length of $0.4 \mathrm{~nm}$ (Rief and others, 1997; Mueller and others, 1999), these two prominent saw-teeth correspond to the extension of polypeptides whose contour lengths (fully extended length) are 290 and $545 \mathrm{~nm}$. Again, taking $0.4 \mathrm{~nm}$ as the average length scale of an amino acid, these curves correspond to proteins composed of approximately 725 and 1365 amino acids (see fig. 1D). This information was used to identify proteins of interest in 2D gels and subsequent mass spectrometry sequencing (see below).

Approach and retraction force measurements, similar to those shown in figure 1, were also conducted with $S$. oneidensis and goethite under aerobic conditions. As a control, we also measured forces between $S$. oneidensis and diaspore. These force measurements are not shown herein but they will be discussed in more detail in the Discussion section.

\section{Two-Dimensional Protein Electrophoresis and Protein Identification}

The genome of $S$. oneidensis MR-1 consists of a 5 Mbp nucleotide sequence encoding 4,758 predicted protein encoding sequences (CDSs) and a $162 \mathrm{kbp}$ extrachromosomal plasmid that encodes an additional 173 CDSs (Heidelberg and others, 2002). Using the genome sequence, we constructed a hypothetical proteome for $S$. oneidensis MR-1 (not shown). This theoretical map revealed that $\sim 87$ percent of the predicted proteins have a $\mathrm{pI}$ between $\mathrm{pH} 3$ to 10 and a $\mathrm{M}_{\mathrm{r}}$ between $10-100 \mathrm{kDa}, \sim 3$ percent have 


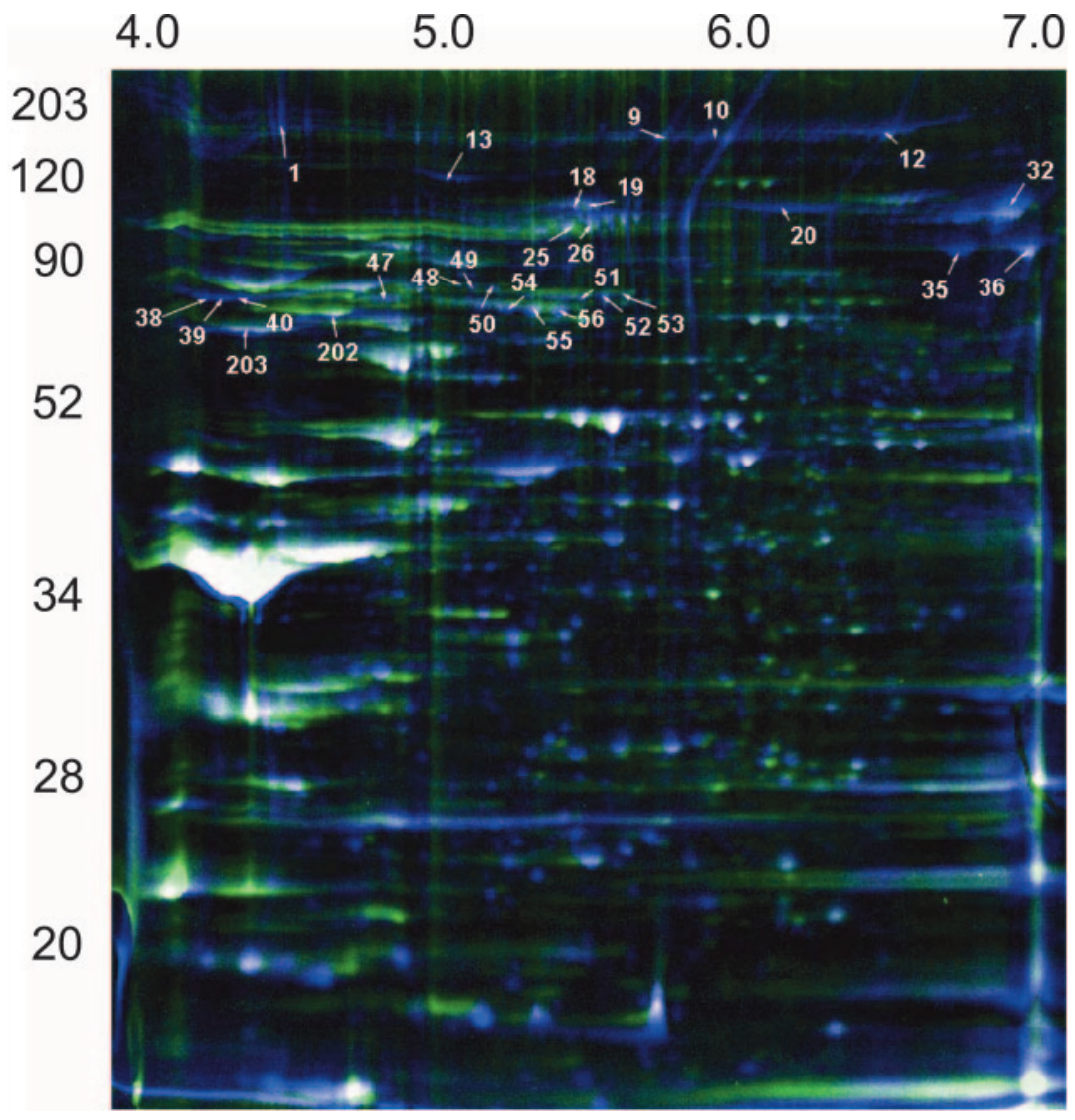

Fig. 2. Two-dimensional gel electrophoresis of $S$. oneidensis outer membrane proteins expressed with oxygen (green) versus $\mathrm{Fe}(\mathrm{III})$ (blue) as the terminal electron acceptor. The $\mathrm{pH}$ gradient of the first dimension is shown across the top and the approximate positions of the molecular mass standards (in kDa) used for SDS-PAGE are at the left. Gels were stained with SYPRO Ruby, imaged, pseudocolored, warped to align protein spots, and digitally overlaid using Delta2D software (DECODON). Green spots correspond to OM proteins that were expressed exclusively or predominately in aerobically grown cells, blue spots are OM proteins expressed exclusively or predominately in cells grown under anaerobic Fe(III) reducing conditions, and white spots are proteins expressed under both conditions. An arrow and number denotes the position of each protein spot identified in table 1.

$\mathrm{M}_{\mathrm{r}}$ values above $100 \mathrm{kDa}, \sim 10$ percent have $\mathrm{pI}$ values greater than a $\mathrm{pH}$ of 10 . No proteins were predicted to have $\mathrm{pI}$ values less than $\mathrm{pH}$ 3. Therefore, we chose to focus proteins in the first dimension using $\mathrm{pH} 3$ to $10 \mathrm{IEF}$ strips and then separate proteins in the second dimension using 10 percent SDS polyacrylamide gels, conditions at which the vast majority of proteins should be observed as predicted by the hypothetical proteome. It should be noted that $\mathrm{pH}$ 4-7 IEF strips were also used to better resolve those polypeptides having isoelectric points within a more circumneutral $\mathrm{pH}$ range.

Figure 2 shows superimposed SYPRO Ruby stained 2D gels of OM extract obtained from $S$. oneidensis grown under anaerobic Fe(III) reducing (blue spots) or aerobic (green spots) conditions. White spots in figure 2 are proteins observed under both conditions. Approximately 1,000 protein spots were resolved per gel (large format $18 \mathrm{~cm} \mathrm{pH} 3-10 \mathrm{IEF}$ and $20 \mathrm{~cm} \times 20 \mathrm{~cm}$ SDS-PAGE), with the majority observed between $\mathrm{pI} 4.0$ to 7.0 and $\mathrm{M}_{\mathrm{r}} 20$ to $100 \mathrm{kDa}$. Many of the protein spots occur as "protein-chains" having indistinguishable molecular masses but visibly different isoelec- 


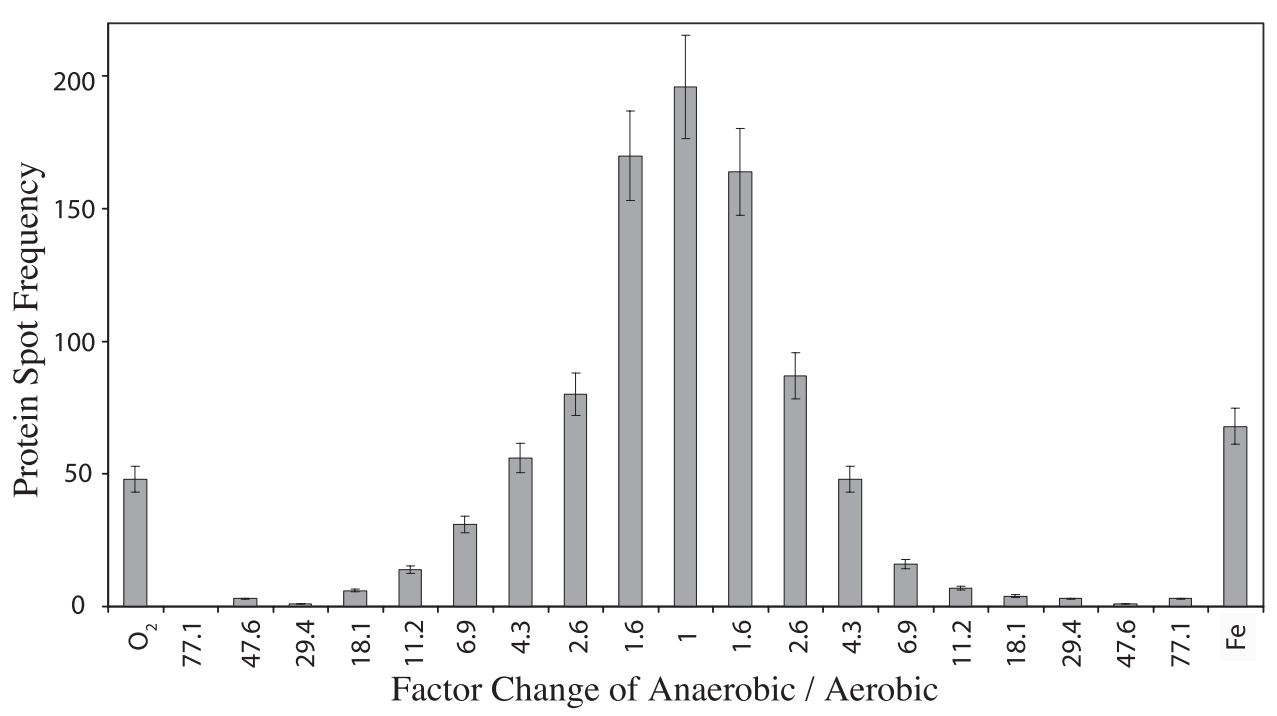

Fig. 3. Symmetric ratio of OM proteins observed with $\mathrm{Fe}(\mathrm{III})$ versus oxygen as the terminal electron acceptor. The Delta2D software $($ DECODON) was used to compare the relative quantities of all $(\sim 1000)$ membrane protein spots observed from 2D gels of Fe(III) versus oxygen grown S. oneidensis. Shown is the fold increase (values to the right of 1) or fold decrease (values to the left of 1) of Fe(III)-expressed OM proteins from triplicate experiments. A majority of membrane proteins are expressed under both conditions (represented as a "factor change" of 1). The proteins that are only observed under aerobic or anaerobic $\mathrm{Fe}(\mathrm{III})$ reducing conditions are denoted by $\mathrm{O}_{2}$ or $\mathrm{Fe}$, respectively.

tric points (see fig. 2). Electrophoretic behavior of this nature is often indicative of post-translational modifications, such as phosphorylation or glycosylation, or perhaps artificial chemical modifications that may have occurred during protein preparation (Larsen and others, 2001; Harrison and others, 2002; Mann and Jensen, 2003). If this is indeed the case then one can speculate that of the $\sim 1,000$ protein spots observed per 2D gel, many are actually the same protein that behaves as multiple species during IEF due to the absence or presence of a covalent modification. Indeed, the results of the MS analysis (discussed below) show that this is the case for many of the protein-chains.

Using the Delta2D software to analyze triplicate 2D gels (that is, large format 2D gels consisting of $18 \mathrm{~cm} \mathrm{pH} 3$ to 10 IEF strips and $20 \mathrm{~cm} \times 20 \mathrm{~cm} 10$ percent SDS-PAGE), we were able to determine that most protein spots $(\sim 60 \%)$ exhibited $<$ 2-fold difference in expression for the two different terminal electron acceptors used in the experiments. That is, $\sim 60$ percent of the proteins were observed to occur under both aerobic and anaerobic Fe(III) reducing conditions. However, $\sim 250$ protein spots exhibited 2 to 10 fold differences in abundance, while $\sim 150$ protein spots showed $>10$-fold difference in abundance between the two electron acceptor conditions (fig. 3).

Thirty of the protein spots that showed $>2$-fold abundance when Fe(III) was the terminal electron acceptor, were selected for MS analysis (see numbered spots in fig. 2, and list of protein spots in table 1). The selection of these 30 spots was guided in large part by the BFM measurements that were compared to the worm-like chain model. As discussed above, these force data seemed to capture the biomechanical signature emitted by putative polypeptides that formed an attractive bond with goethite. Two of the most prominent force-signatures were identified as originating from the extension of OM proteins composed of 725 and 1365 amino acids. Using the average mass of an amino acid $(\sim 110 \mathrm{Da})$, this corresponds to proteins having a molecular mass $\left(\mathrm{M}_{\mathrm{r}}\right)$ of 
TABLE 1

Outer membrane proteins displaying increased abundance when grown under anaerobic $\mathrm{Fe}(I I I)$ reducing conditions compared to aerobic conditions

\begin{tabular}{|c|c|c|c|c|c|c|c|c|}
\hline Spot no. & ORF & Putative Function & $\mathbf{M r}$ & pl & Ratio & TM & Lipid & ID \\
\hline 1 & S00224 & DNA-directed RNA polymerase RpoB & 150 & 5.28 & $\mathrm{Fe}$ & No & No & Both \\
\hline 9 & S00224 & DNA-directed RNA polymerase RpoB & 150 & 5.28 & 30.2 & No & No & MS/MS \\
\hline 9,10 & S01779 & decaheme cytochrome OmcA & 78.6 & 6.36 & 30.2 & Yes & Yes & MS/MS \\
\hline 10 & S00224 & DNA-directed RNA polymerase RpoB & 150 & 5.28 & $\mathrm{Fe}$ & No & No & MS/MS \\
\hline 12 & NA & Unknown & NA & NA & 3.8 & NA & NA & NA \\
\hline 13 & S00404 & hypothetical & 129 & 5.13 & $\mathrm{Fe}$ & Yes & Yes & Both \\
\hline 18 & S04211 & SecAsubunit & 102 & 5.26 & $\mathrm{Fe}$ & Yes & No & Both \\
\hline 19 & S04211 & SecAsubunit & 102 & 5.26 & 10.5 & Yes & No & MS/MS \\
\hline 20 & S01204 & translation initiation factor $\mathrm{I} 2-\mathrm{F}$ & 95.1 & 5.93 & $\mathrm{Fe}$ & Yes & No & Both \\
\hline 25 & S03193 & polysaccharide biosynthesis/export protein & 100 & 5.66 & 15.8 & Yes & No & Both \\
\hline 26 & S03193 & polysaccharide biosynthesis/export protein & 100 & 5.65 & 15.8 & Yes & No & MS/MS \\
\hline 32 & S01521 & iron-sulfur cluster-binding protein & 99.8 & 6.59 & 3.6 & Yes & No & Both \\
\hline 35,36 & S00848 & periplssmic nitrate reductase NapA & 92.5 & 8.06 & 16.8 & Yes & No & Both \\
\hline 38 & S01776 & $\mathrm{MtrB}$ & 77.6 & 4.62 & $\mathrm{Fe}$ & Yes & No & MS/MS \\
\hline 39,40 & S0 1776 & $\mathrm{MtrB}$ & 77.6 & 4.62 & $\mathrm{Fe}$ & Yes & No & Both \\
\hline 47 & S01126 & chaperone protein DnaK(HSP7O) & 68.8 & 4.77 & $\mathrm{Fe}$ & Yes & No & Both \\
\hline 48,50 & S00166 & general secretion pathway GspD & 76.8 & 5.46 & 20 & Yes & No & Both \\
\hline 49 & S00166 & general secretion pathway GspD & 76.8 & 5.46 & $\mathrm{Fe}$ & Yes & No & MS/MS \\
\hline 51 & S03844 & peptidase, M13 family & 77.2 & 5.52 & 2.8 & Yes & Yes & Both \\
\hline 52 & S03844 & peptidase, M13 family & 772 & 5.52 & 4.6 & Yes & Yes & MS/MS \\
\hline 53 & S03844 & peptidase, M13 family & 77.2 & 5.52 & $\mathrm{Fe}$ & Yes & Yes & Both \\
\hline 54 & S04408 & virulence regulator $\mathrm{BipA}$ & 65.5 & 5.06 & $\mathrm{Fe}$ & Yes & No & MS/MS \\
\hline 55 & S00404 & hypothetical protein & 129 & 5.13 & 2.8 & Yes & Yes & Both \\
\hline 56 & S00404 & hypothetical protein & 129 & 5.13 & 3.4 & Yes & Yes & MS/MS \\
\hline 202 & S03545 & OmpA family protein & 402 & 4.76 & 2.3 & Yes & No & Both \\
\hline 203 & S01854 & hypothetical & 664 & 4.86 & 2.7 & Yes & No & MS/MS \\
\hline
\end{tabular}

The spot numbers (Spot no.) refer to the protein spot numbers given in fig. 2. The open reading frame encoding each protein is given as "ORF", and was used as provided by the National Center for Biotechnology Information (NCBI; http:/ / www.ncbi.nlm.nih.gov). The protein identification method (ID) used to identify each spot is indicated by "MS/MS" when tandem mass spectrometry was used, "PMF" when peptide mass fingerprinting was used, or "Both" when PMF and MS/MS were both used. The putative protein function, theoretical protein mass $\left(\mathrm{M}_{\mathrm{r}}\right.$, given in $\left.\mathrm{kDa}\right)$, and theoretical isoelectric point $(\mathrm{pI})$ were used as provided by the NCBI. "Ratio" referes to the averaged relative expression values from three replicate 2D gels of OM extract from $S$. oneidensis grown under anaerobic Fe(III) reducing conditions compared to that of cells grown under aerobic conditions ("Fe" indicates the spot was observed only under anaerobic Fe(III) reducing conditions). Putative transmembrane domains (TM) were identified using the dense alignment surface method (Cserzo and others, 1997), which predicts transmembrane alpha-helices in prokaryotic organisms. Putative OM lipoprotein lipid attachment sites (Lipid) were identified using ScanProsite (Gattiker and others, 2002). "NA" means not applicable.

$\sim 80$ and $\sim 150 \mathrm{kDa}$ respectively. Therefore, we selected the larger protein spots $(>70-80 \mathrm{kDa})$ for MS identification.

The section of the gel containing each of the polypeptides of interest was excised, placed in separate siliconized microcentrifuge tubes and sent to the Michigan Proteome Consortium (University of Michigan, Ann Arbor, Michigan) for tryptic digestion, MALDI-MS analysis, and MS/MS analysis. Since peptide mass fingerprint (PMF) data is often not sufficient for the positive identification of a protein, tamdem mass spectrometric analysis (MS/MS) was used in addition to PMF to unambiguously identify the proteins. Table 1 summarizes the protein spots that were sequenced with MALDI-MS and/or MS/MS.

Spots 1,9 , and 10 were determined to contain a putative DNA-dependent RNA polymerase. This protein was extremely abundant in 2D gels and poorly focused in the first dimension despite the lengthy IEF times (that is, 75,000 Vh). As a result it appears as a streaked pattern at $\sim 150 \mathrm{kDa}$ (see fig. 2) that co-migrates with other protein spots 


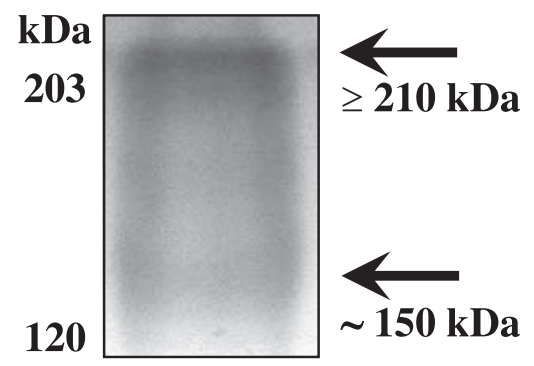

$\geq 210$ kDa Band

$\begin{array}{clc}\begin{array}{c}\text { Start-End } \\ 407-421\end{array} & \begin{array}{l}\text { Peptide Sequence } \\ \text { ATINDAGKLVYTTTK }\end{array} & \text { ID } \\ & & \\ & & \\ \text { 150 kDa Band } & \\ \text { Start-End } & \text { Peptite Sequence } & \text { ID } \\ 408-421 & \text { NNALTFDVQILDNK } & \text { OmcA } \\ 643-653 & \text { SNVVTGIALGR } & \text { OmcA }\end{array}$

Fig. 4. Identification of $\mathrm{OM}$ proteins obtained from cells grown under anaerobic $\mathrm{Fe}(\mathrm{III})$ reducing conditions. Proteins were resolved on parallel 10\% SDS-PAGE gels, one gel was heme stained to detect cytochromes and the other gel was stained with SYPRO Ruby for MS analysis. Shown on the top is the heme stained gel, with the approximate positions of the molecular weight markers down the left side (kDa), and arrows indicating the positions of the $\sim 150 \mathrm{kDa}$ and $\geq 210 \mathrm{kDa}$ heme stained bands. Shown on the bottom are the peptides identified, with the peptide sequence and corresponding protein identification (ID). The MS analysis indicated that other protein species were also present in each band, however the identity of these were not included because we were only interested in determining the presence or absence of cytochromes.

having a similar $\mathrm{M}_{\mathrm{r}}$. Two such spots (9 and 10) were found to contain a second polypeptide that was identified by MS/MS as OmcA, a decaheme cytochrome believed to be involved in $\mathrm{Fe}(\mathrm{III})$ and $\mathrm{Mn}(\mathrm{IV})$ reduction (Myers and Myers, 1998, 2001). However, OmcA has a predicted molecular mass of $\sim 79 \mathrm{kDa}$, which is about half the size of the $\sim 150 \mathrm{kDa}$ protein spots (that is, spots 9 and 10) observed in the 2D gel. We hypothesized that its retarded electrophoretic migration reflected incomplete denaturing of the polypeptide in the IEF buffer, and thus this protein was behaving as an oligomer during 2D gel electrophoresis.

In an attempt to resolve this discrepancy, proteins contained within the OM extract of cells grown under anaerobic Fe(III) reducing conditions were resolved by one-dimensional SDS-PAGE, and stained for heme content following the protocol of Myers and Myers (2001). Seven heme-positive protein bands were observed at $\sim 20$, $\sim 25, \sim 40, \sim 50, \sim 80, \sim 150$, and $\geq 210 \mathrm{kDa}$. The corresponding $\sim 80, \sim 150$, and $\geq 210$ $\mathrm{kDa}$ heme-stained bands from a parallel SYPRO Ruby stained gel were excised and sequenced by MS/MS analysis. As we expected, MS/MS analysis detected multiple protein species in each of the bands. Two peptides from the $\sim 150 \mathrm{kDa}$ band were matched $(p<0.05)$ to OmcA (fig. 4$)$, which is consistent with the 2D gel. Rather surprisingly, one peptide species from the $\geq 210 \mathrm{kDa}$ band $(\mathrm{p}<0.05)$ was determined to come from another decaheme cytochrome, MtrC (see fig. 4), which was previously described by Myers and Myers (2001), Myers and Myers (2003), and Beliaev and others (2001). The MS/MS data obtained from the $\sim 80 \mathrm{kDa}$ protein band was very poor and as a consequence we were unable to determine the identity of proteins contained 
within this band, however the positive heme stain suggests that this protein band contains a cytochrome.

It should be noted that while proteins greater than $150 \mathrm{kDa}$ were observed in 1D gels they are noticeably absent in 2D gels. This is not uncommon as many high molecular weight proteins are unable to enter the acrylamide in the IEF strips during rehydration and are thus absent in 2D gels (see 2D electrophoresis methods from Amersham Biosciences). In this study we noted that active rehydration of the IEF strips was absolutely necessary to observe proteins $>100 \mathrm{kDa}$ in $2 \mathrm{D}$ gels.

Returning to the 2D gels, spots 38, 39, and 40 (observed only under anaerobic $\mathrm{Fe}$ (III) reducing conditions) were positively identified as the OM protein MtrB. This protein was previously shown to be essential for both $\mathrm{Fe}$ (III) and $\mathrm{Mn}$ (IV) reduction in $S$. oneidensis and is believed to be part of an operon containing $m t r A$, which encodes an $\sim 36 \mathrm{kDa}$ decaheme cytochrome (Beliaev and Saffarini, 1998). Spots 35 and 36, which displayed $\sim 3$-fold increase in protein expression under anaerobic Fe(III) reducing conditions, were both identified by PMF and MS/MS as a putative nitrate reductase, NapA, that has been shown to be essential for nitrate reduction in other bacteria (Potter and Cole, 1999; Potter and others, 2001). Spot 32, which exhibited $\sim 4$-fold more abundance under Fe(III) reducing conditions, was identified as a putative iron-sulfur cluster binding protein (Frazzon and others, 2002; Kiley and Beinert, 2003) encoded by ORF SO1521.

Spots 13, 55, 56, and 203 were identified as hypothetical proteins having unknown biological functions. Spots 13, 55, 56 were unambiguously identified by both PMF and MS/MS analysis as the same hypothetical protein encoded by ORF SO0404 and predicted to have a $\mathrm{M}_{\mathrm{r}}$ of $\sim 125 \mathrm{kDa}$ (see table 1). Spot 13 was observed exclusively in gels of $\mathrm{OM}$ extract from cells grown under anaerobic Fe(III) reducing conditions. The fact that spot 13 has a $\mathrm{M}_{\mathrm{r}}$ on 2D gels of $\sim 125 \mathrm{kDa}$, while spots 55 and 56 have a $\mathrm{M}_{\mathrm{r}}$ of $\sim$ $80 \mathrm{kDa}$ suggests that this protein undergoes proteolysis prior to IEF. It is also predicted to contain an OM leader sequence and prokaryotic lipoprotein lipid attachment site (see table 1).

A putative virulence regulator, BipA GTPase (Farris and others, 1998; Grant and others, 2003), was identified from spot 54 . Spots 48, 49, and 50 were all identified as a putative, general, secretion pathway protein D (GspD; Gerard-Vincent and others, 2002) and exhibited a $>20$-fold increase in abundance under anaerobic Fe(III) reducing conditions. Spots 18 and 19 were identified as a putative preprotein translocase protein, Sec A, that has been previously shown to play an important role in protein export (Lill and others, 1989; de Keyzer and others, 2003). Spots 51, 52, and 53 were identified as a putative M13 family peptidase, which is predicted to contain an OM leader sequence and prokaryotic lipoprotein lipid attachment site (table 1). Spots 25 and 26 were both identified as a putative polysaccharide biosynthesis/export protein encoded by ORF SO3193 (Yoshida and others, 2003), and predicted to contain up to two N-terminal transmembrane domains.

Spot 20, which was observed exclusively for anaerobic Fe(III) reducing conditions, occurred as a diffuse protein-chain and was identified as a putative translation initiation factor (IF-2), which in other organisms functions in the formation of the first peptide bond of nascent polypeptides (Vachon and others, 1990). Spot 47, which was 2-fold more abundantly under anaerobic Fe(III) reducing conditions, was identified as a putative chaperon protein (DnaK) encoded by ORF SO1126 (Dougan and others, 2002). We were unable to definitively identify the prominent protein-chain labeled as spot 12 in figure 2 due to the poor quality of MS data that was obtained for this sample. Since this protein is so prominent in $2 \mathrm{D}$ gels and observed only under anaerobic $\mathrm{Fe}$ (III) reducing conditions, efforts are currently underway to identify the protein(s) contained within this chain. 
DISCUSSION

A great deal is known about the transfer of electrons from S. oneidensis to Fe(III) (Arnold and others, 1990; Myers and Nealson, 1990; Myers and Myers, 1992; DiChristina and Delong, 1994; Roden and Zachara, 1996; Caccavo and others, 1997; Fredrickson and others, 1998; Zachara and others, 1998; Caccavo, 1999; Newman and Kolter, 2000; Roden and others, 2000; Hernandez and Newman, 2001; Myers and Myers, 2001, 2002). However, there are at least two fundamental questions that have not been adequately addressed in the literature with respect to electron transfer to solid Fe(III) phases. Do natural forces of affinity exist between metal reducing bacteria and particular metal oxyhydroxide phases? Do bacteria, such as S. oneidensis, produce mineral-specific proteins to mediate interactions with goethite or other minerals containing iron or manganese?

We propose that the genome of $S$. oneidensis preserves the long and intimate history between metal-reducing bacteria and metal oxyhydroxides such that this species produces mineral-specific proteins, which exhibit natural forces of affinity towards select minerals such as goethite (Lower and others, 2001a). These interactions may have been a fundamental mechanism driving the natural selection and propagation of this particular bacterial species, and others like it, on Earth. Indeed other studies have suggested that proteins play a key role in adhesion of dissimilatory metal reducing bacteria to iron oxides (for example, Caccavo, 1999; Das and Caccavo, 2000, 2001) and presumably played a dominate role in the evolutionary longevity of these microorganisms on Earth (Lovley, 1991; Vargas and others, 1998).

Herein we have sought to provide insight into the questions posed above by combining theoretical and experimental force measurements with detailed expression and sequence analyses of specific proteins that might be involved in mediating contact with metal oxides. The Results section describes the use of BFM to discover and probe natural forces of affinity between living cells of $S$. oneidensis and crystalline inorganic surfaces such as goethite. These force data were searched for evidence of putative OM proteins that mediate contact with a mineral using the so-called worm-like chain model, which can be used to predict the theoretical force-extension profile of polypeptides. Differential protein expression patterns, provided by 2D gel electrophoresis, and protein sequences provided by mass spectrometry were used to identify putative mineral-specific proteins that function or assist in mineral binding or the direct transfer of electrons from $S$. oneidensis to ferric iron in a mineral. Below is a thorough discussion of these points.

The approach force measurements (see figs. 1A and 1C) reveal that a cell of $S$. oneidensis must come to within a few nanometers of the goethite surface before experiencing any force of interaction with the mineral. This demonstrates that for unattached, planktonic cells of $S$. oneidensis intermolecular forces are negligible at separations larger than approximately 10 to $100 \mathrm{~nm}$. Force fields may extend outwards to greater distances in solutions of lesser ionic strength (for example, see Lower and others, 2000), but in general bacterial cells must be within a very small distance $(\sim 10$ $\mathrm{nm}$ ) of another surface before intermolecular forces act upon the microorganism's surface.

Perhaps this is the reason that some dissimilatory iron reducing bacteria seem to employ chemotaxis to search for solid phases that may be suitable electron sinks (Childers and others, 2002). Once a cell in solution locates a potential terminal electron accepting mineral, either by chemotaxis or random movements, it is an intermolecular force that dictates the actual physical contact between macromolecules on a bacterium and ferric iron in the crystal structure of a mineral. Contact is considered by many researchers to be a prerequisite for electron transfer between metal reducing bacteria, like Shewanella or Geobacter, and iron oxyhydroxides. Because 
the forces that govern cell-mineral contact are very short range (as shown herein), bacterial recognition of a mineral surface, if it occurs, must require a cell to be in intimate contact with a crystalline surface. Therefore, we will focus the rest of the discussion on the retraction data, which contain the intrinsic sensory acuities that a bacterium experiences when it is in direct physical contact with a mineral. Retraction data in figure 1 (see panels B and D) show a strong attraction between $S$. oneidensis and goethite. We and others (for example, Lower and others, 2000, 2001b; Abu-Lail and Camesano, 2002; Camesano and Abu-Lail, 2002; Abu-Lail and Camesano, 2003; Kendall and Lower, 2004; Lower and others, 2005) have attributed similar attractive forces to bonds formed by macromolecules that are physically linked to another surface. The long-range nature of these bonds is thought to be due to the addition of force (for example, from a force-sensing cantilever) that is required to physically extend a "bridging" polymer (Lower and others, 2001a; Lower and others, 2005). The retraction data, therefore, embody not only the strength of the physical bond between a bacterium and mineral, but also the biophysical mechanics involved in decoupling a cell from a solid surface.

To compare the overall characteristics of each bacterium-mineral-solution permutation (that is, goethite versus diaspore; aerobic versus anaerobic; no "recognition time" versus 20 to 25 minute "recognition time") we determined two parameters for each retraction curve: the adhesion force and the energy (or work). The adhesion force corresponds to the magnitude of the force observed at contact (that is, the origin of the distance axis; see figs. 1B or 1D), and represents a single point of the retraction data. Energy was determined by integrating force with respect to distance for retraction curves. This represents the work that is necessary to completely separate a bacterium from a mineral surface. As such, the energy determinations embody the retraction curves in their entirety. Figure 5 compares the adhesion force and the energy (or work) associated with the retraction data collected for the various experiments including those experiments with diaspore.

The adhesion force has been a useful parameter when dealing with attractive bonds formed by single molecules that do not exhibit long-range interactions (for example, see Noy and others, 1997; Wong and others, 1998). However, it is unlikely to provide a valid benchmark for measurements with whole cells, whose surfaces are a complex mosaic of many different types of molecules. Each energy value, on the other hand, provides a single quantitative number that embodies all interactions between multiple biomolecules and reactive sites on a mineral surface.

Energy (or work) determinations demonstrate that $S$. oneidensis displays a much greater affinity for goethite under anaerobic versus aerobic conditions (fig. 5B). This affinity was significantly impacted by the amount of time that $S$. oneidensis remained in contact with goethite prior to conducting force measurements (see fig. 5B). No such difference in affinity was noted for $S$. oneidensis toward diaspore as a function of oxygen concentration or contact time (see fig. 5). This is despite the fact that goethite and diaspore have very similar surface properties.

These quantitative work determinations suggest that $S$. oneidensis recognizes the surface of goethite as a potential sink for electrons under anaerobic conditions. However, this alone does not provide absolute evidence that S. oneidensis actually recognizes the surface of goethite relative to other similar minerals (for example, diaspore). Perhaps, the strongest evidence for this would come from a demonstration that this microorganism expresses specific proteins for select mineral phases.

There is a distinct and reproducible signature in the retraction profiles for $S$. oneidensis and goethite under anaerobic conditions, particularly those experiments in which the bacterium remained in contact with the mineral for an extended period of time. These particular retraction traces reveal a number of discrete, jagged, sawtooth 

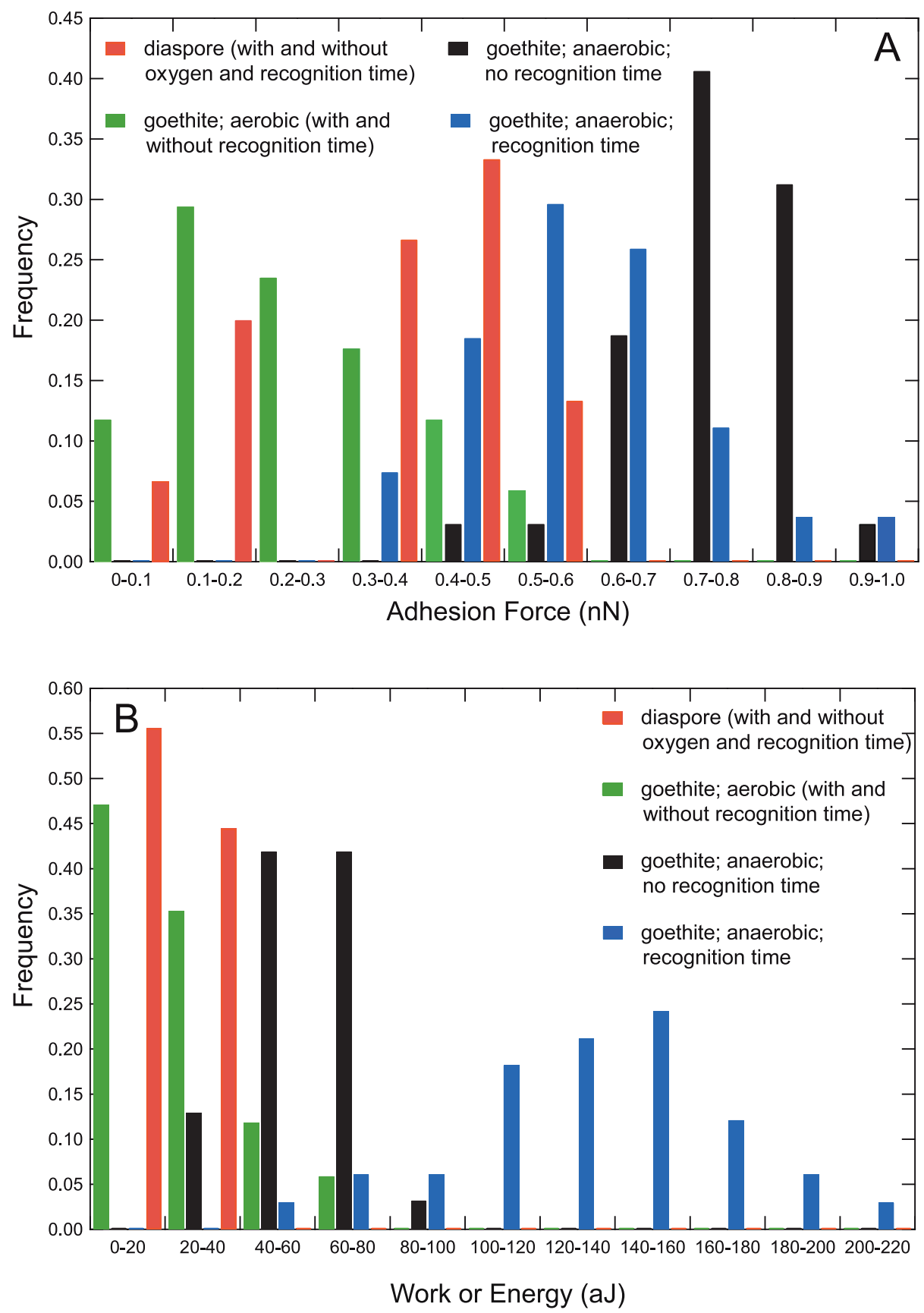

Fig. 5. Histogram summarizing (A) the adhesion force (that is, value for force at a distance equal to zero) and (B) energy (or work; in attoJoules $=10^{-18} \mathrm{~J}$ ) associated with retraction data like that presented in figures $1 \mathrm{~B}$ and $1 \mathrm{D}$. All force and energy values are attractive (the negative sign has been dropped for clarity). Each scenario represents the culmination of 20-40 retraction curves collected for each combination of mineral, oxygen concentration, and contact time using two $S$. oneidensis biologically-active-force-probes. Diaspore data did not exhibit a significant difference in force or energy as a function of oxygen concentration nor contact time between the bacteria and mineral. Likewise there was no significant difference as a function of contact time for goethite under aerobic conditions. Therefore, all permutations for these two scenarios were grouped and plotted as one. 
like features, or regions where the force increases in a nonlinear fashion and then suddenly snaps back towards the line representing zero force (see fig. 1D). These features are not exclusive to the anaerobic interaction between $S$. oneidensis and goethite. For example, Lower and others (2001a) noted a similar feature for the interaction between $S$. oneidensis and goethite under aerobic conditions. Likewise, some sawtooth features have been detected in our laboratory for the interaction between $S$. oneidensis and diaspore. However, saw-teeth detected for these latter two interactions (that is, $S$. oneidensis interactions with diaspore, or goethite under aerobic conditions) are, in general, less frequent and relatively short-range (occurring over distances of $<100 \mathrm{~nm}$ ). The longer range sawtooth features appear to be a hallmark for $S$. oneidensis-goethite retraction traces collected in anaerobic solutions. Lower and others (2001a) observed similar long-range saw-teeth in $\sim 80$ percent of the retraction force measurements between $S$. oneidensis and goethite under anaerobic conditions.

In the past, we have hypothesized that sawtooth like features in retraction profiles represent the unraveling of OM proteins that have formed bonds with the surface of a mineral (Lower and others, 2001a). Recently, we showed that specific sawteeth could be attributed to the formation of a bond between a protein expressed on the surface of a bacterial cell and a solid substrate, in-situ (Lower and others, 2005). This is supported by the work of others who have made similar observations using a force microscope to extend (or stretch) purified proteins (Rief and others, 1997; Mueller and others, 1999; Muller and others, 1999; Oesterhelt and others, 2000). To understand the reason proteins display a sawtooth extension profile one needs only to consider the native state of a protein that is exposed to water. A polymer, such as a protein, that is exposed to aqueous solution will bend and curve locally as a result of thermal fluctuations (Bustamante and others, 2000). These entropically driven interactions with a solvent lead to a coiled conformation for most proteins. The higher entropy created by a folded or coiled (as opposed to a linear) structure is thermodynamically favorable.

As illustrated in the Results section, the entropically-driven, coiled state of polymers can be described theoretically by the worm-like chain model (see equation 1 ). This model is valid for polymers whose primary structure is linear, which includes all proteins (and nucleic acids) as well as some polysaccharides. However, many bacterially produced polysaccharides exist naturally in a branched conformation. For example, Vinogradov and others (2003) present the branched structure of a polysaccharide from $S$. oneidensis. This branched nature is the result of glycosidic bonds between sugars, which have more degrees of freedom than the one-dimensional peptide bond within a polypeptide.

Comparing the observed and theoretical force-distance relationships for retraction curves, suggests that polypeptides are responsible for the sawtooth like features between $S$. oneidensis and goethite (for example, see fig. 1D). As mentioned in the Results section, the two most prominent sawteeth observed between $S$. oneidensis and goethite correspond to the theoretical worm-like chain profiles for polypeptides composed of 725 and 1365 amino acids. Figure 1D reveals that the predicted curve for the 725 amino acid polypeptide had to be translated vertically by $\sim 0.2 \mathrm{nN}$ to match the measured sawtooth between 200 to $250 \mathrm{~nm}$. The worm-like chain model curve for the 725 amino acid protein shown in figure 1D has not been translated laterally (that is, the extension distance has not been altered). Nor, does this translation alter the relative forces that are predicted by the worm-like chain model. Only the absolute values of the predicted force-separation curves are altered by the magnitude of the offset (that is, approximately $0.2 \mathrm{nN}$ ).

This offset may be valid if one considers that other macromolecules (for example, lipopolysaccharides, polysaccharides, and/or smaller polypeptides) are probably involved in the attractive interaction observed within the first $100 \mathrm{~nm}$. Indeed, other 
publications have shown that biomolecules like these are responsible for attractive forces observed within $\sim 100 \mathrm{~nm}$ (for example, see Lower and others, 2000). These other biomolecules would likely overprint the extension profile of smaller proteins by an additional force beyond that which would be observed for stretching the protein only. In a previous publication (Lower and others, 2001a), we reported evidence of only the larger 1365 amino acid protein. However, the figure presented in that same publication (see fig. 1 in Lower and others, 2001a) does indeed show a sawtooth feature near 200 to $250 \mathrm{~nm}$, which is similar to the 725 amino acid sawtooth in figure 1D. In our previous publication we did not explore the possibility that other macromolecules may overprint the absolute force extension necessary to stretch a protein of interest (for example, $\mathrm{a} \sim 80 \mathrm{kDa}$ protein composed of $\sim 725$ amino acids).

The predicted worm-like chain curves show a stronger nonlinear response at longer extension lengths relative to the average retraction trace in figure 1D. This is in part due to the averaging procedure (that is, not all retraction measurements show a sawtooth at this length scale). But, more so this may be due to the model, which was developed for a protein in a solvent such as water. It is true that the proteins we are probing are likely exposed to water because they have to exist on the outer surface of $S$. oneidensis to be detected in these particular force experiments. However, the proteins that are being probed in these measurements are also, at least in part, on or within the $\mathrm{OM}$ of $S$. oneidensis. The evidence for this comes from individual saw-teeth, which can be seen repeatedly in consecutive traces collected within seconds to minutes of one another (for example, compare individual traces in the region between 100-250 $\mathrm{nm}$ in fig. 1D). It appears that an OM protein is stretched until it snaps back onto the cell surface. Forces intrinsic to the protein or between the protein and the lipopolysaccharides of the OM must maintain the integrity of the protein in the cell wall, and prevent it from stretching to larger length scales before recoiling back into (or onto) the cell wall. Intrinsic forces between a native protein and the cell wall within which it is embedded would seek to counteract any force that attempts to pull the protein away from the cell surface. This would result in a smaller magnitude nonlinear response as observed in figure 1D. Interestingly, the structure (and presumably function) of these proteins are probably not damaged by their extension because, as stated above, sawtooth features are reproducible in traces that were collected within several seconds to minutes of one another. This idea of the intrinsic resilience of proteins is supported by another force microscopy study in which a protein was observed to refold to its original, native state in under one second after being extended by a force probe (Rief and others, 1997).

In summary, the force data compared to the worm-like chain model indicate that under anaerobic conditions, polypeptides are present in the $\mathrm{OM}$ of $S$. oneidensis that function to mediate contact between the bacterium and the surface of goethite. This appears to be a mineral specific interaction that is controlled by the bacteria as no reproducible polypeptide force-signatures were detected between $S$. oneidensis and diaspore, nor were protein force-signatures detected in control experiments with nonviable cells of $S$. oneidensis (Lower and others, 2001a).

This is one of the reasons that we turned to 2D gel electrophoresis to identify OM proteins that may play a pivotal role in mediating contact and electron transfer between $S$. oneidensis and iron oxyhydroxides. At first glance, it may seem difficult to compare electrophoresis data to force-distance curves collected with BFM. However, the ability of the worm-like chain model to predict the primary sequence (that is, the number of amino acids) associated with particular force-signatures, allows a straightforward comparison of BFM and 2D gel electrophoresis. The comparison is as simple as converting a putative, polypeptide's contour length into a molecular mass using the average size $(0.4 \mathrm{~nm})$ and mass $(110 \mathrm{Da})$ of an amino acid. Hence, we can search 2D 
electrophoresis gels for protein spots in a size range that is comparable to those polypeptides implicated by experimental and theoretical force measurements as being localized to the bacterium-mineral interface.

The protocol we employed for the enrichment of OM proteins developed by Molloy and others (2000) offers a simplified yet reproducible extraction method for the isolation of OM proteins that is amenable to micropreparative 2D gel electrophoresis and MS analysis. Indeed many of the proteins identified in this study are predicted to be lipoproteins, integral/transmembrane proteins, or are already known (MtrB, OmcA, OmpA) to be associated with the OM (see table 1). We also used two other methods that were developed to purify proteins from the OM of bacteria (Schnaitman, 1971; Leisman and others, 1995). The 2D gels of OM extract obtained by these two purification methods exhibited very similar protein patterns to those observed in the 2D gels presented here (B. Lower, unpublished data). However, the quality of the 2D gels resulting from these two procedures was relatively poor (that is, horizontal and vertical streaking were observed throughout the gels), which made it difficult to compare the protein expression patterns using the Delta2D (DECODON) software. As a result, the method of Molloy and others (2000) was used in this study. Nevertheless, it bears mentioning, that all 30 protein spots selected for MS analysis and identified in table 1, were also visible in gels prepared by the protocol of Schnaitman (1971) and Leisman and others (1995).

Major differences in protein expression patterns were observed when 2D gel electrophoresis was performed on OM extract from $S$. oneidensis grown aerobically versus cells grown anaerobically with $\mathrm{Fe}$ (III) as the terminal electron acceptor (fig. 2). Up to 1000 protein spots were resolved on each gel with many $(\sim 40 \%)$ of these preferentially expressed under one growth condition (figs. 2 and 3). However, as noted in the Results section, many of the polypeptides occur as discrete protein-chains having similar $\mathrm{M}_{\mathrm{r}}$ but different isoelectric points. We speculate that these proteinchains are actually composed of the same protein that behaves as multiple species during IEF due to the absence or presence of a covalent modification. The results of the MS analysis (table 1) support this notion as many of the protein spots analyzed from the 2D gels were identified as the same protein. For example, spots 38, 39, and 40 from a protein-chain shown in figure 2, were all identified as MtrB. This raises an intriguing possibility that post-translational modifications, such as phosphorylation or glycosylation, may play an important role in Fe(III) reduction. However, that is beyond the scope of this paper.

We used PMF and MS/MS to identify outer membrane proteins that (1) showed an increased abundance under anaerobic Fe(III) reducing conditions compared to aerobic conditions and (2) were similar in size to those polypeptides implicated by force data as possibly being localized to the bacterium-mineral interface (see fig. 1). Several of the proteins that were identified in this study are known to have, or are predicted to have, biological functions that are critical to dissimilatory metal reduction.

For example, GspD (identified from spots 48, 49, and 50), exhibits 34 percent homology to $\mathrm{XcpQ}$, an $\mathrm{OM}$ protein involved in the type II secretion system of Pseudomonas aeruginosa (Martinez and others, 1998), a system used by many Gramnegative bacteria to translocate exoproteins across the OM ( Pugsley, 1993; Bleves and others, 1999). The gene encoding GspD (SO0166) is located just upstream of another type II secretion gene, gspE (designated ferE by DiChristina and others, 2002), and part of an adjacent cluster of 12 putative type II secretion genes $(g s p C$-gs $p N)$. DiChristina and others (2002) demonstrated that FerE is absolutely essential for anaerobic growth on $\mathrm{Fe}(\mathrm{III})$ and $\mathrm{Mn}(\mathrm{IV})$ and provided evidence that a type II secretion pathway is responsible for transporting cytochromes in their fully mature forms to the OM of $S$. 
oneidensis. It is intriguing to speculate that GspD also performs a role in the type II transport of cytochromes to the outer face of $S$. oneidensis, however further work needs to be preformed to determine this possibility.

While GspD was purified from OM extract of $S$. oneidensis and has a predicted $\mathrm{M}_{\mathrm{r}}$ of $\sim 77 \mathrm{kDa}$ (corresponding to 704 amino acids), it seems unlikely that this protein is responsible for generating the sawtooth feature corresponding to a 725 amino acid polypeptide $(\sim 80 \mathrm{kDa})$ in the force curves (see fig. 1D). Homologs of GspD (for example $\mathrm{XcpQ}$ ) are known to assemble as ring-shaped channels within the $\mathrm{OM}$ of bacteria. Therefore, it seems unlikely that this protein would be fully exposed on the outer face of a cell where it would be most accessible to the force-sensing interface of the BFM.

More reasonable candidates for matching the 725 amino acid sawtooth feature observed in the force data are proteins such as OmcA, MtrB, or MtrC (also known as $\mathrm{OmcB}$ ). All of these proteins were identified in $\mathrm{OM}$ extract of $\mathrm{Fe}(\mathrm{III})$ reducing cells (see table 1 and fig. 4). All of these proteins have molecular masses of $\sim 80 \mathrm{kDa}$ (equivalent to $\sim 725$ amino acids). And, all of these proteins are known to be required for dissimilatory metal reduction (Myers and Myers, 1998; Beliaev and others, 2001; Myers and Myers, 2001). Therefore, the 725 amino acid sawtooth feature observed in figure $1 \mathrm{D}$ could be due to the binding of one or more of these proteins $(\mathrm{OmcA}, \mathrm{MtrB}$, or MtrC) to the goethite surface under anaerobic solutions.

The above discussion identifies proteins that may be responsible for generating the smaller sawtooth shown in figure 1D. However, we have still not correlated the larger sawtooth (see 1365 amino acid curve in fig. 1D) to the 2D electrophoresis data. The genome of $S$. oneidensis contains ORFs encoding several putative OM proteins composed of 1350 to 1400 amino acids (for example, SOA0110, SOA0112, and SOA0115). However, these larger proteins were not actually identified in the larger protein spots $(\geq 150 \mathrm{kDa})$ on the $1 \mathrm{D}$ or $2 \mathrm{D}$ electrophoresis gels. This could be due in part (as discussed in the Results section) to the inability of these large $\mathrm{M}_{\mathrm{r}}$ proteins to enter the IEF strips prior to 2D gel electrophoresis. Alternatively, these proteins may not be involved in binding to iron oxides or Fe(III) reduction.

Of the larger protein spots observed on the 1D and 2D gels, MS/MS analyses identified them as OmcA and MtrC. OmcA, for example, was identified from spots corresponding to a $\mathrm{M}_{\mathrm{r}}$ of $\sim 150 \mathrm{kDa}$ on a 2D gel (spots 9 and 10 in fig. 2) and from the $\sim 150 \mathrm{kDa}$ protein band on a $1 \mathrm{D}$ gel (fig. 4). MtrC was identified from the protein band with a $\mathrm{M}_{\mathrm{r}}$ of $\geq 210 \mathrm{kDa}$ in figure 4. This is puzzling as the $\mathrm{M}_{\mathrm{r}}$ of OmcA and MtrC are predicted to be $\sim 79 \mathrm{kDa}$ and $\sim 72 \mathrm{kDa}$ respectively and not $\sim 150$ and $\sim 210 \mathrm{kDa}$. In fact, the largest putative cytochrome predicted to be encoded by the genome of $S$. oneidensis is $<100 \mathrm{kDa}$. This might suggest that the MS analysis misidentified these two proteins. However, heme-positive bands larger than $100 \mathrm{kDa}$ were observed in SDSPAGE gels and MS/MS analysis identified OmcA from both spots 9 and 10 in the 2D gel (fig. 2). Furthermore, MS/MS analysis of the $\sim 150 \mathrm{kDa}$ protein band from the 1D gel (fig. 4) matched ( $p<0.05)$ two peptides to OmcA as well. It is worth noting, though, that only one peptide was matched to MtrC in figure 4 . Therefore its identification should be viewed with caution until we can more definitively identify the proteins contained within this band (for example match $>1$ peptide to MtrC). However, as noted above, heme staining suggests the presence of c-type cytochromes in the $\geq 210 \mathrm{kDa}$ protein band observed on $1 \mathrm{D}$ gels.

Other researchers have also observed similar high $\mathrm{M}_{\mathrm{r}}$ heme-stained protein bands in SDS-PAGE gels of OM extract from S. oneidensis (Myers and Myers, 1992; Myers and Myers, 2001). Based on these data, we propose that the large ( $>100 \mathrm{Da}$ ) heme-stained protein bands consist of cytochromes (and perhaps other proteins) that are not completely denatured during electrophoresis and as such migrate as larger oligomers 
(for example, OmcA may behave as a homodimer) during electrophoresis. If this is the case, then it would suggest that these proteins may associate together to form some sort of terminal reductase complex that functions to transfer electrons from the cell surface to the surface of the metal oxide under anaerobic conditions. Outer membrane oligomers would, of course, result in sawteeth that were larger than expected based on the primary sequence of individual proteins found in the hypothetical proteome of $S$. oneidensis. A homodimer of OmcA (or MtrC) would, for example, consist of 1350 to 1500 amino acids, which is similar in size to the larger sawtooth shown in figure 1D.

It is beyond the scope of this paper to provide a definitive answer as to which OM proteins are responsible for mediating contact and subsequent electron transfer from $S$. oneidensis to a metal oxide. However, this combined approach using BFM and 2D electrophoresis coupled to MS/MS, has significantly narrowed the number of likely candidates. Studies are currently underway to answer this question using genetically engineered strains of $S$. oneidensis that overexpress (or do not express) the individual OM proteins (that is, OmcA, MtrB, MtrC, and others) highlighted above. This work should provide us with a great deal of insight into the structure and function of these $\mathrm{OM}$ proteins in electron transfer to metal oxide surfaces, in-situ.

Finally, the above discussion is not meant to imply that polysaccharides are not important in mediating contact and subsequent iron reduction between metal reducing bacteria and metal oxyhydroxides. In fact, we believe that shorter range $(<50-100$ $\mathrm{nm}$ ) attractive forces between $S$. oneidensis and goethite (see figs. $2 \mathrm{~B}$ and D) are the result of different types of macromolecules including polysaccharides. This view is supported by the proteomic data, which shows that a protein punitively involved in polysaccharide biosynthesis and export (spots 25 and 26 in fig. 2 and table 1) displayed a $>10$-fold increase in expression under anaerobic $\mathrm{Fe}(\mathrm{III})$ reducing conditions. Likewise we should not rule out the possibility that some of the hypothetical proteins identified in this study may play an important role in dissimilatory metal reduction as well.

\section{CONCLUSION}

We have shown that under anaerobic conditions $S$. oneidensis responds to the surface of goethite by rapidly developing stronger forces of attraction towards the mineral. Comparison of retraction force profiles to a theoretical model for protein unfolding (that is the worm-like chain model), indicates that $S$. oneidensis actively mobilizes putative mineral-specific proteins that mediate contact with goethite. Two proteins in particular were singled out. These include polypeptides composed of 725 or 1365 amino acids, which are equivalent to proteins with masses of $\sim 80$ and $\sim 150$ $\mathrm{kDa}$, respectively. Examination of OM protein expression profiles of S. oneidensis with 2D gel electrophoresis reveals that many proteins are differentially expressed when oxygen versus $\mathrm{Fe}$ (III) is used as the terminal electron acceptor. Mass spectrometric analysis identified a number of proteins including decaheme cytochromes involved in electron transport (MtrB, MtrC, and OmcA) and a protein (GspD) involved in a type II protein secretion system. These data, taken together, suggest that $S$. oneidensis recognizes the surface of goethite and produces putative iron oxyhydroxide-specific proteins (for example, $150 \mathrm{kDa}$ and $80 \mathrm{kDa}$ proteins), which play a key role in the reduction of Fe(III) in solid phases.

\section{ACKNOWLEDGMENTS}

Funding for this research was provided to BHL and MFH by the Department of Energy (DE-FG02-02ER15326), with partial support for MFH from the National Science Foundation (EAR-0103053) and partial support for BHL from the DOE Natural and Accelerated Bioremediation Research Program (NABIR), Office of Biological and Environmental Research (OBER). Pacific Northwest National Laboratory is 
operated for the Department of Energy by Battelle. Support for SKL was provided by the Department of Energy (DE-FG02-04ER15590) with partial support from the American Chemical Society for SKL (38107-G2). SKL also acknowledges the National Science Foundation for providing funds for the integrated scanning probe microscope / confocal laser scanning microscope (EAR-0411935). This work benefited from discussion with J. Chen and J. Fredrickson. We thank M. Schreiber for kindly allowing us to use her anaerobe chamber, and B. Potters and A. Madden for their assistance in the laboratory. Two anonymous reviewers provided constructive criticism that greatly improved the original manuscript. SKL greatly appreciates the support of J. Tak and BHL the support of BCHM.

\section{REFERENCES}

Abu-Lail, N. I., and Camesano, T. A., 2002, Elasticity of Pseudomonas putida KT2442 surface polymers probed with Single-Molecule Force Microscopy: Langmuir, v. 18, p. 4071-4081.

2003, Role of lipopolysaccharides in the Adhesion, Retention, and Transport of Escherichia coli JM109: Environmental Science and Technology, v. 37, p. 2173-2183.

Arnold, R. G., DiChristina, T. J., and Hoffmann, M. R., 1988, Reductive dissolution of Fe(III) oxides by Pseudomonas sp. 200: Biotechnology and Bioengineering, v. 32, p. 1081-1096.

Arnold, R. G., Hoffmann, M. R., Dichristina, T. J., and Picardal, F. W., 1990, Regulation of Dissimilatory $\mathrm{Fe}$ (Iii) Reduction Activity in Shewanella-Putrefaciens: Applied and Environmental Microbiology, v. 56, p. 2811-2817.

Beliaev, A. S., and Saffarini, D. A., 1998, Shewanella putrefaciens mtrB encodes an outer membrane protein required for $\mathrm{Fe}(\mathrm{III})$ and $\mathrm{Mn}(\mathrm{IV})$ reduction: Journal of Bacteriology, v. 180, p. 6292-7.

Beliaev, A. S., Saffarini, D. A., McLaughlin, J. L., and Hunnicutt, D., 2001, MtrC, an outer membrane decahaem c cytochrome required for metal reduction in Shewanella putrefaciens MR-1: Molecular Microbiology, v. 39, p. 722-30.

Bleves, S., Gerard-Vincent, M., Lazdunski, A., and Filloux, A., 1999, Structure-function analysis of XcpP, a component involved in general secretory pathway-dependent protein secretion in Pseudomonas aeruginosa: Journal of Bacteriology, v. 181, p. 4012-9.

Bustamante, C., Smith, S. B., Liphardt, J., and Smith, D., 2000, Single-molecule studies of DNA mechanics: Current Opinion Structural Biology, v. 10, p. 279-85.

Caccavo, F., 1999, Protein-mediated adhesion of the dissimilatory Fe(III)-reducing bacterium Shewanella alga BrY to hydrous ferric oxide: Applied and Environmental Microbiology, v. 65, p. 5017-5022.

Caccavo, F., Jr., Schamberger, P. C., Keiding, K., and Nielsen, P. H., 1997, Role of hydrophobicity in adhesion of the dissimilatory Fe(III)-reducing bacterium Shewanella alga to amorphous Fe(III) oxide: Applied and Environmental Microbiology, v. 62, p. 3837-3843.

Camesano, T. A., and Abu-Lail, N. I., 2002, Heterogeneity in bacterial surface polysaccharides, probed on a single-molecule basis: Biomacromolecules, v. 3, p. 661-667.

Childers, S. E., Ciufo, S., and Lovley, D. R., 2002, Geobacter metallireducens accesses insoluble Fe(III) oxide by chemotaxis: Nature, v. 416, p. 767-769.

Cleveland, J. P., Manne S., Bocek D., and Hansma, P. K., 1993, A nondestructive method for determining the spring constant of cantilevers for scanning force microscopy: Review of Scientific Instruments, v. 64, p. 403-405.

Cserzo, M., Wallin, E., Simon, I., vonHeijne, G., and Elofsson, A., 1997, Prediction of transmembrane alpha-helices in prokaryotic membrane proteins: the dense alignment surface method: Protein Engineering, v. 10 , p. $673-676$.

Das, A., and Caccavo, F., 2000, Dissimilatory Fe(III) oxide reduction by Shewanella alga BrY requires adhesion: Current Microbiology, v. 40, p. 344-347.

— 2001, Adhesion of the dissimilatory Fe(III)-reducing bacterium Shewanella alga BrY to crystalline Fe(III) oxides: Current Microbiology, v. 42, p. 151-154.

D'Costa, N. P., and Hoh, J. H., 1995, Calibration of Optical-Lever Sensitivity for Atomic-Force Microscopy: Review of Scientific Instruments, v. 66, p. 5096-5097.

de Keyzer, J., van der Does, C., and Driessen, A. J., 2003, The bacterial translocase: a dynamic protein channel complex: Cellular and Molecular Life Sciences, v. 60, p. 2034-52.

DiChristina, T. J., and Delong, E. F., 1994, Isolation of anaerobic respiratory mutants of Shewanella putrefaciens and genetic analysis of mutants deficient in anaerobic growth on $\mathrm{Fe}^{3+}$ : Journal of Bacteriology, v. 176, p. 1468-1474.

DiChristina, T. J., Moore, C. M., and Haller, C. A., 2002, Dissimilatory Fe(III) and Mn(IV) reduction by Shewanella putrefaciens requires ferE, a homolog of the pulE (gspE) type II protein secretion gene: Journal of Bacteriology, v. 184, p. 142-51.

Dougan, D. A., Mogk, A., and Bukau, B., 2002, Protein folding and degradation in bacteria: to degrade or not to degrade? That is the question: Cellular and Molecular Life Sciences, v. 59, p. 1607-16.

Ducker, W. A., Senden, T. J., and Pashley, R. M., 1992, Measurements of forces in liquids using a force microscope: Langmuir, v. 8, p. 1831-1836.

Farris, M., Grant, A., Richardson, T. B., and O'Connor, C. D., 1998, BipA: a tyrosine-phosphorylated GTPase that mediates interactions between enteropathogenic Escherichia coli (EPEC) and epithelial cells: Molecular Microbiology, v. 28, p. 265-79. 
Flory, P. J., 1989, Statistical Mechanics of Chain Molecules: Munich, Hanser Publishers, 432 p.

Frazzon, J., Fick, J. R., and Dean, D. R., 2002, Biosynthesis of iron-sulphur clusters is a complex and highly conserved process: Biochemical Society Transactions, v. 30, p. 680-5.

Fredrickson, J. K., and Gorby, Y. A., 1996, Environmental processes mediated by iron-reducing bacteria: Current Opinion in Biotechnology, v. 7, p. 287-294.

Fredrickson, J. K., Zachara, J. M., Kennedy, D. W., Dong, H., Onstott, T. C., Hinman, N. W., and Li, S-M., 1998, Biogenic iron mineralization accompanying the dissimilatory reduction of hydrous ferric oxide by a groundwater bacterium: Geochimica et Cosmochimica Acta, v. 62, p. 3239-3257.

Fujiki, Y., Hubbard, A. L., Fowler, S., and Lazarow, P. B., 1982, Isolation of Intracellular Membranes by Means of Sodium-Carbonate Treatment - Application to Endoplasmic-Reticulum: Journal of Cell Biology, v. 93, p. 97-102.

Gattiker, A., Gasteiger, E., and Bairoch, A., 2002, ScanProsite: a reference implementation of a PROSITE scanning tool: Applied Bioinformatics, v. 1, p. 107-8.

Gerard-Vincent, M., Robert, V., Ball, G., Bleves, S., Michel, G. P., Lazdunski, A., and Filloux, A., 2002, Identification of $\mathrm{XcpP}$ domains that confer functionality and specificity to the Pseudomonas aeruginosa type II secretion apparatus: Molecular Microbiology, v. 44, p. 1651-65.

Gorg, A., Postel, W., Gunther, S., and Weser, J., 1985, Improved horizontal two-dimensional electrophoresis with hybrid isoelectric focusing in immobilized $\mathrm{pH}$ gradients in the first dimension and laying-on transfer to the second dimension: Electrophoresis, v. 6, p. 599-604.

Gorg, A., Postel, W., and Gunther, S., 1988, The Current State of Two-Dimensional Electrophoresis with Immobilized Ph Gradients: Electrophoresis, v. 9, p. 531-546.

Grant, A. J., Farris, M., Alefounder, P., Williams, P. H., Woodward, M. J., and O'Connor, C. D., 2003, Co-ordination of pathogenicity island expression by the BipA GTPase in enteropathogenic Escherichia coli (EPEC): Molelcular Microbiology, v. 48, p. 507-21.

Harrison, M. J., Wathugala, I. M., Tenkanen, M., Packer, N. H., and Nevalainen, K. M. H., 2002, Glycosylation of acetyhylan esterase from Trichoderma reesei: Glycobiology, v. 12, p. 291-298.

Heidelberg, J. F., Paulsen, I. T., Nelson, K. E., Gaidos, E. J., Nelson, W. C., Read, T. D., Eisen, J. A., Seshadri, R., Ward, N., Methe, B., Clayton, R. A., Meyer, T., Tsapin, A., Scott, J., Beanan, M., Brinkac, L., Daugherty, S., DeBoy, R. T., Dodson, R. J., Durkin, A. S., Haft, D. H., Kolonay, J. F., Madupu, R., Peterson, J. D., Umayam, L. A., White, O., Wolf, A. M., Vamathevan, J., Weidman, J., Impraim, M., Lee, K., Berry, K., Lee, C., Mueller, J., Khouri, H., Gill, J., Utterback, T. R., McDonald, L. A., Feldblyum, T. V., Smith, H. O., Venter, J. C., Nealson, K. H., and Fraser, C. M., 2002, Genome sequence of the dissimilatory metal ion-reducing bacterium Shewanella oneidensis: Nature Biotechnology, v. 20, p. 1118-23.

Hernandez, M. E., and Newman, D. K., 2001, Extracellular electron transfer: Cellular and Molecular Life Sciences, v. 58, p. 1562-1571.

Jaschke, M., and Butt, H. J., 1995, Height calibration of optical lever atomic force microscopes by simple laser interferometry: Review of Scientific Instruments, v. 66, p. 1258-1259.

Kendall, T. A., and Hochella, M. F., 2003, Measurement and interpretation of molecular-level forces of interaction between the siderophore azotobactin and mineral surfaces: Geochimica et Cosmochimica Acta, v. 67, p. 3537-35456.

Kendall, T. A., and Lower, S. K., 2004, Forces between minerals and biological surfaces in aqueous solution: Advances in Agronomy, v. 82, p. 1-54.

Kiley, P. J., and Beinert, H., 2003, The role of Fe-S proteins in sensing and regulation in bacteria: Current Opinion in Microbiology, v. 6, p. 181-5.

Laemmli, U. K., 1970, Cleavage of structural proteins during the assembly of the head of bacteriophage T4: Nature, v. 227 , p. $680-685$.

Larsen, M. R., Larsen, P. M., Fey, S. J., and Roepstorff, P., 2001, Characterization of differently processed forms of enolase 2 from Saccharomyces cerevisiae by two-dimensional gel electrophoresis and mass spectrometry: Electrophoresis, v. 22, p. 566-575.

Leisman, G. B., Waukau, J., and Forst, S. A., 1995, Characterization and Environmental Regulation of Outer Membrane Proteins in Xenorhabdus nematophilus: Applied and Environmental Microbiology, v. 61 p. $200-4$.

Lill, R., Cunningham, K., Brundage, L. A., Ito, K., Oliver, D., and Wickner, W., 1989, SecA protein hydrolyzes ATP and is an essential component of the protein translocation ATPase of Escherichia coli: The EMBO Journal, v. 8, p. 961-6.

Lovley, D. R., 1991, Dissimilatory Fe(III) and Mn(IV) Reduction: Microbiological Reviews, v. 55, p. 259-287. 2001, Bioremediation. Anaerobes to the rescue: Science, v. 293, p. 1444-6.

Lovley, D. R., and Phillips, E. J. P., 1986, Availability of Ferric Iron for Microbial Reduction in Bottom Sediments of the Fresh-Water Tidal Potomac River: Applied and Environmental Microbiology, v. 52, p. $751-757$.

_ 1988, Novel mode of microbial energy metabolism: Organic carbon oxidation coupled to dissimilatory reduction of iron or manganese: Applied and Environmental Microbiology, v. 54, p. 1472-1480.

Lovley, D. R., Phillips, E. J. P., Gorby, Y. A., and Landa, E. R., 1991a, Microbial reduction of uranium: Nature, v. 350, p. 413-416.

Lovley, D. R., Phillips, E. J. P., and Lonergan, D. J., 1991b, Enzymatic Versus Nonenzymatic Mechanisms for Fe(III) Reduction in Aquatic Sediments: Environmental Science and Technology, v. 25, p. 1062-1067.

Lower, B. H., Yongsunthon, R., Vellano III, F. P., and Lower, S. K., 2005, Simultaneous force and fluorescence measurements of a protein that forms a bond between a living bacterium and a solid surface: Journal of Bacteriology, v. 187, p. 2127-2137.

Lower, S. K., Tadanier, C. J., and Hochella, M. F., 2000, Measuring interfacial and adhesion forces between bacteria and mineral surfaces with biological force microscopy: Geochimica et Cosmochimica Acta, v. 64 , p. 3133-3139. 
Lower, S. K., Hochella, M. F., and Beveridge, T. J., 2001a, Bacterial recognition of mineral surfaces: Nanoscale interactions between Shewanella and a-FeOOH: Science, v. 292, p. 1360-1363.

2001b, Dynamics of the mineral-microbe interface: Use of biological force microscopy in biogeochemistry and geomicrobiology: Geomicrobiology Journal, v. 18, p. 63-76.

Mann, M., and Jensen, O. N., 2003, Proteomic analysis of post-translational modifications: Nature Biotechnology, v. 21, p. 255-261.

Martinez, A., Ostrovsky, P., and Nunn, D. N., 1998, Identification of an additional member of the secretin superfamily of proteins in Pseudomonas aeruginosa that is able to function in type II protein secretion: Molecular Microbiology, v. 28, p. 1235-46.

Molloy, M. P., Herbert, B. R., Slade, M. B., Rabilloud, T., Nouwens, A. S., Williams, K. L., and Gooley, A. A., 2000, Proteomic analysis of the Escherichia coli outer membrane: European Journal of Biochemistry, v. 267, p. 2871-2881.

Molloy, M. P., Phadke, N. D., Maddock, J. R., and Andrews, P. C., 2001, Two-dimensional electrophoresis and peptide mass fingerprinting of bacterial outer membrane proteins: Electrophoresis, v. 22, p. 16861696.

Mueller, H., Butt, H. J., and Bamberg, E., 1999, Force measurements on myelin basic protein adsorbed to mica and lipid bilayer surfaces done with the atomic force microscope: Biophysical Journal, v. 76, p. 1072-1079.

Muller, D. J., Baumeister, W., and Engel, A., 1999, Controlled unzipping of a bacterial surface layer with atomic force microscopy: Proceedings of the National Academy of Sciences of the United States of America, v. 96, p. 13170-13174.

Myers, C. R., and Myers, J. M., 1992, Localization of cytochromes to the outer membrane of anaerobically grown Shewanella Putrefaciens MR-1: Journal of Bacteriology, v. 174, p. 3429-3438.

- 1997, Outer membrane cytochromes of Shewanella putrefaciens MR-1: Spectral analysis, and purification of the 83-kDa $c$-type cytochrome: Biochimica et Biophysica Acta, v. 1326, p. 307-318.

_ 2003, Cell surface exposure of the outer membrane cytochromes of Shewanella oneidensis MR-1: Letters in Applied Microbiology, v. 37, p. 254-8.

Myers, C. R., and Nealson, K. H., 1988, Bacterial manganese reduction and growth with manganese oxide as the sole electron acceptor: Science, v. 240, p. 1319-1321.

- 1990, Respiration-linked proton translocation coupled to anaerobic reduction of manganese(IV) and iron(III) in Shewanella putrefaciens MR-1: Journal of Bacteriology, v. 172, p. 6232-6238.

Myers, J. M., and Myers, C. R., 1998, Isolation and sequence of omcA, a gene encoding a decaheme outer membrane cytochrome $c$ of Shewanella putrefaciens MR-1, and detection of omcA homologs in other strains of S. putrefaciens: Biochimica et Biophysica Acta, v. 1373, p. 237-251.

2000, Role of the tetraheme cytochrome CymA in anaerobic electron transport in cells of Shewanella putrefaciens MR-1 with normal levels of menaquinone: Journal of Bacteriology, v. 182, p. 67-75.

2001, Role for outer membrane cytochromes OmcA and OmcB of Shewanella putrefaciens MR-1 in reduction of manganese dioxide: Applied and Environmental Microbiology, v. 67, p. 260-269.

2002, Genetic complementation of an outer membrane cytochrome omcB mutant of Shewanella putrefaciens MR-1 requires omcB plus downstream DNA: Applied and Environmental Microbiology, v. 68 , p. 2781-2793.

Newman, D. K., and Kolter, R., 2000, A role for excreted quinones in extracellular electron transfer: Nature, v. 405 , p. $94-97$.

Noy, A., Vezenov, D. V., and Lieber, C. M., 1997, Chemcial Force Microscopy: Annual Review of Materials Science, v. 27, p. 381-421.

Oesterhelt, F., Oesterhelt, D., Pfeiffer, M., Engel, A., Gaub, H. E., and Muller, D. J., 2000, Unfolding pathways of individual bacteriorhodopsins: Science, v. 288, p. 143-146.

Potter, L. C., and Cole, J. A., 1999, Essential roles for the products of the napABCD genes, but not napFGH, in periplasmic nitrate reduction by Escherichia coli K-12: Biochemical Journal, v. 344 Pt 1, p. 69-76.

Potter, L., Angove, H., Richardson, D., and Cole, J., 2001, Nitrate reduction in the periplasm of gramnegative bacteria: Advances in Microbial Physiology, v. 45, p. 51-112.

Pugsley, A. P., 1993, The complete general secretory pathway in gram-negative bacteria: Microbiological Reviews, v. 57, p. 50-108.

Rief, M., Gautel, M., Oesterhelt, F., Fernandez, J. M., and Gaub, H. E., 1997, Reversible unfolding of individual titin immunoglobulin domains by AFM: Science, v. 276, p. 1109-1112.

Roden, E. E., and Zachara, J. M., 1996, Microbial reduction of crystalline iron(III) oxides: Influence of oxide surface area and potential for cell growth: Environmental Science and Technology, v. 30, p. 1618-1628.

Roden, E. E., Urrutia, M. M., and Mann, C. J., 2000, Bacterial reductive dissolution of crystalline Fe(III) oxide in continuous-flow column reactors: Applied and Environmental Microbiology, v. 66, p. 10621065 .

Rosso, K. M., Zachara, J. M., Fredrickson, J. K., Gorby, Y. A., and Smith, S. C., 2003, Nonlocal bacterial electron transfer to hematite surfaces: Geochimica et Cosmochimica Acta, v. 67, p. 1081-1087.

Santoni, V., Molloy, M., and Rabilloud, T., 2000, Membrane proteins and proteomics: un amour impossible?: Electrophoresis, v. 21, p. 1054-70.

Schnaitman, C. A., 1971, Solubilization of the cytoplasmic membrane of Escherichia coli by Triton X-100: Journal of Bacteriology, v. 108, p. 545-52.

Stipp, S. L. S., and Hochella, M. F., Jr., 1991, Structure and bonding environments at the calcite surface as observed with X-ray photoelectron-spectroscopy (XPS) and low-energy electron-diffraction (LEED): Geochimica et Cosmochimica Acta, v. 55, p. 1723-1736.

Urrutia, M. M., Roden, E. E., and Zachara, J. M., 1999, Influence of aqueous and solid-phase Fe(II) complexants on microbial reduction of crystalline iron(III) oxides: Environmental Science and Technology, v. 33, p. 4022-4028. 
Vachon, G., Laalami, S., Grumberg-Manago, M., Julien, R., and Cenatiempo, Y., 1990, Purified internal G-domain of translational initiation factor IF-2 displays guanine nucleotide binding properties: Biochemistry, v. 29, p. $9728-33$.

Vargas, M., Kashefi, K., Blunt-Harris, E. L., and Lovley, D. R., 1998, Microbiological evidence for Fe(III) reduction on early Earth: Nature, v. 395, p. 65-7.

Wong, S. S., Woolley, A. T., Joselevich, E., Li Cheung, C. L., and Lieber, C. M., 1998, Covalentlyfunctionalized single-walled carbon nanotube probe tips for chemical force microscopy: Journal of the American Chemical Society, v. 120, p. 8557-8558.

Yoshida, T., Ayabe, Y., Yasunaga, M., Usami, Y., Habe, H., Nojiri, H., and Omori, T., 2003, Genes involved in the synthesis of the exopolysaccharide methanolan by the obligate methylotroph Methylobacillus sp. strain 12S: Microbiology, v. 149, p. 431-44

Vinogradov, E., Korenevsky, A., and Beveridge, T. J., 2003, The structure of the rough-type lipopolysaccharide from Shewanella oneidensis MR-1, containing 8-amino-8-deoxy-Kdo and an open-chain form of 2-acetamido-2-deoxy-D-galactose: Carbohydrate Research, v. 338, p. 1991-1997.

Zachara, J. M., Fredrickson, J. K., Li, S-M., Kennedy, D. W., Smith, S. C., and Gassman, P. L., 1998, Bacterial reduction of crystalline $\mathrm{Fe}^{3+}$ oxides in single phase suspensions and subsurface materials: American Mineralogist, v. 83, p. 1426-1443. 